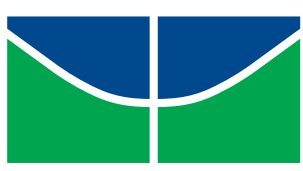

Universidade de Brasília

Instituto de Ciências Humanas

Departamento de Filosofia

SAMUEL GONÇALVES GARRIDO

\title{
REFLEXÕES SOBRE O NADA E O NÃO SER
}

MONOGRAFIA

Brasília

2017 


\section{SAMUEL GONÇALVES GARRIDO}

\section{REFLEXÕES SOBRE O NADA E O NÃO SER}

Trabalho de monografia apresentado ao Departamento de Filosofia da Universidade de Brasília, como parte dos requisitos necessários à obtenção do título de Licenciado em Filosofia.

Orientador: Prof. Dr. Alexandre Costa-Leite 
Dedico este trabalho a todos e todas que vivem sob a penumbra do nada; amigos e amigas (existentes ou não), paroxismos e pulsões que tornaram possível concretizar este estudo. 


\section{Agradecimentos}

Agradeço aos meus amigos e amigas pelo apoio e compreensão: Marcelo Garrido (amigo e pai), Jussara Garrido, Gabriel Garrido, Jéssika Montanha, Mayã Fernandes, Luan Lima, Pedro Poney, David S. Araya, Thiago Satyr, Marcos Rizatto, Susane R. de Oliveira, Marcos Del Valle, Tati Lionço e Caio Couto Sampaio. Todos e todas que acompanharam minha graduação e contribuíram com conversas, provocações, sugestões e desgastes mentais.

Registro também meu agradecimento e admiração aos professores envolvidos neste processo: Prof. Erick Lima e prof. Marcos Aurélio Fernandes, pelo apoio e comentários extremamente construtivos. Meu orientador, professor e amigo, Alexandre Costa-Leite, que tanto me auxiliou no desenvolvimento do presente estudo, propiciando um conhecimento que transformou a minha forma de pensar a filosofia e a condição humana. 
Talvez o sofrimento não tenha justificativa alguma, assim como a existência, em geral. A existência deveria existir? Há alguma razão no fato de existir? Ou a existência não teria outra razão senão uma imanente? A existência existe apenas como existência? O ser é apenas ser? Por que não admitirmos um triunfo final do não ser, por que não admitirmos que a existência se encaminha para o Nada e o ser para o não ser? Não seria o não ser a única realidade absoluta? Eis um paradoxo à altura do paradoxo deste mundo.

(E. M. Cioran) 


\section{Resumo}

O presente trabalho tem como intento refletir sobre as concepções acerca "do" nada no pensamento filosófico. Em síntese, o problema é:_Será (o) nada algo? Acusado como inquilino da experiência, (o) nada enquanto objeto possível esbarra na incapacidade de um apelo ontológico. Assim, ao passo que conceber e representar algo envolve ter uma relação com o que é representado mediante a apreensão de uma particularidade, como podemos estabelecer uma relação constitutiva com o que não é e, ao que tudo indica, não existe? Será possível lidar com algo que carece de existência, representação e não se reduz ao essencial? Por este obstáculo, cogito pensar (o) nada amparado pela ideação da existência de objetos não existentes, buscando dissecar as razões que circunscrevem seu conceito, comumente apontado como contraditório ou mal formado. Tamanho esforço, uma vez voltado para a vivência de suas consequências, aclara o profundo mal-estar que cinge a autocompreensão de nosso tempo e se manifesta enquanto niilismo. Isso significa que se (o) nada é tomado como algo e, consequentemente, como causa para a aniquilação de pressupostos metafísicos e morais, devemos também elucidar o que podemos saber sobre as estruturas intrínsecas a esse objeto. Portanto, essa escrita prende-se à inquirição e análise do conceito de um objeto não existente, orbitando sobre (o) nada e seus encadeamentos, perscrutando a possibilidade de uma ontologia do não ser.

Palavras Chave: Nada, Ser, não ser, ontologia, verdade, realidade, niilismo, ceticismo, semântica, discurso, lógica. 


\section{Sumário}

Introdução $\ldots \ldots \ldots \ldots \ldots \ldots$

$1 \quad$ Pressupostos ....................... 12

$1.1 \quad$ O Ser e o não ser (Parmênides) $\ldots \ldots \ldots \ldots$

$1.2 \quad$ O paradoxo do não ser (existenciais negativos) $\ldots \ldots \ldots$. . . . . . . . . . 19

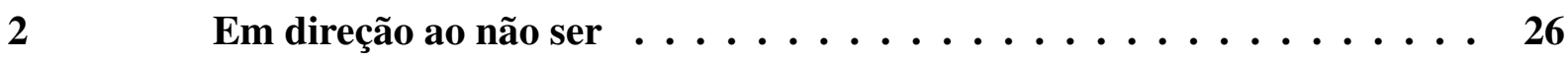

2.1 Intencionalidade e objetos não existentes $\ldots \ldots \ldots \ldots \ldots$

$2.2 \quad$ acesso "ao" nada (semântica e operadores) $\ldots \ldots \ldots \ldots$

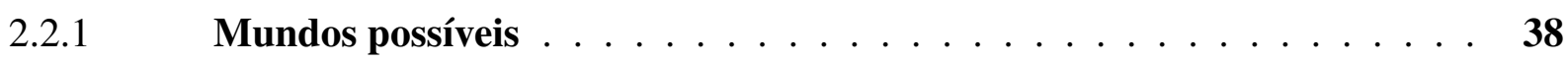

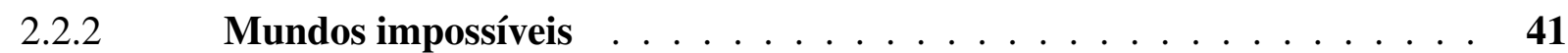

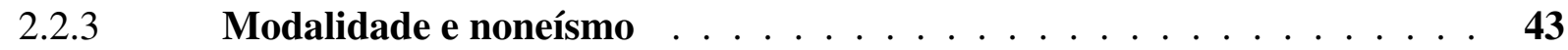

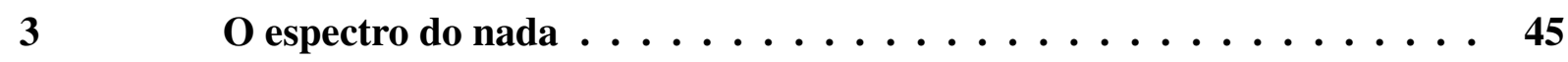

$3.1 \quad$ Niilismo, devir e o retorno à Parmênides . . . . . . . . . . . . . . . 51

CONCLUSÃo .............................. 58

Referências Bibliográficas . . . . . . . . . . . . . . 63 


\section{Introdução}

O presente trabalho tem como intento refletir sobre as concepções acerca do nada no pensamento filosófico. Através desse esforço, busca-se indagar suas implicações teoréticas enquanto objeto metafísico, lógico e existencial (no campo da moral).

Em síntese, o problema é:_Será (o) ${ }^{1}$ nada algo? Acusado como inquilino da experiência, (o) nada aparece já nas controvérsias que marcaram o nascimento da ontologia ocidental, i.e., tomado enquanto objeto possível, esbarra na incapacidade de um apelo ontológico. Assim, ao passo que conceber e representar algo envolve ter uma relação com o que é representado mediante a apreensão de uma particularidade, como podemos estabelecer um vínculo constitutivo com o que não é e, ao que tudo indica, ${ }^{2}$ não existe? Será possível lidar com (algo) que carece de existência, representação e não se reduz ao essencial? Com isso lidaremos com o questionamento de proposições basilares que enunciam critérios para indicar o que é o "existir" e o "real" visando nosso objeto de estudo.

Por este obstáculo, cogito pensar (o) nada amparado pela ideação da existência de objetos não existentes, buscando dissecar as razões que circunscrevem seu conceito, comumente apontado como contraditório ou mal formado. Tamanho esforço, uma vez voltado para a vivência de suas consequências, aclara o profundo mal-estar que "se abre como uma rachadura para a autocompreensão de nosso tempo" (pág. 7), ${ }^{3}$ efetivando o niilismo. Isso significa que se (o) nada é tomado como algo e, consequentemente, como causa para a aniquilação de pressupostos metafísicos e morais, devemos também elucidar o que podemos saber sobre as estruturas intrínsecas a esse objeto, ou seja, se é o caso que (o) nada é tomado com aquele capaz de ratificar o niilismo, convém compreender os mecanismos imanentes ao nada e que legitimam sua manifestação. Portanto, esta escrita prende-se à inquirição e análise do conceito de um objeto não existente, orbitando sobre (o) "nada" e seus encadeamentos, perscrutando a possibilidade de uma ontologia do não ser.

O texto é dividido em três partes e subsumido a uma conexão da lógica com a metafísica, i.e., uma interação lógico-ontológica. Considera-se tal metodologia com a finalidade de exercer a metafísica pautada nos nossos próprios limites de inferência e demarcada pelo pensar. Por esta premissa, procuro assimilar a apreensão da natureza de uma realidade através da análise de uma semântica e como esta se relaciona com proposições. Em suma, trata-se de analisar e denunciar as formas de inferências que aceitamos como válidas, sendo estas as que

1 O uso dos parênteses é uma esforço gramatical visto que (o) nada, nada é. Ao se colocar como não ser ou simplesmente um não-substantivo, designar o nada como sendo algo indica o nada enquanto Ser, podendo funcionar numa sentença como sujeito ou objeto. Até então não pretendo apontar (o) nada como aquele que designa substância, essência de algo.

2 Afirmar a existência do nada é afirmar que existe algo que não existe. Segundo o princípio da não contradição não é possível existir algo que seja contraditório.

3 VOLPI, Franco. O Niilismo. São Paulo: Edições Loyola, 1999. 
representam e evidenciam as nossas diferentes concepções do Ser, ${ }^{4}$ verdade e imputações de existência.

A primeira etapa do estudo cumpre delimitar o que significa lidar com o conceito de um objeto não existente, igualmente perquirindo: O que é (o) nada? - Com isso, buscamos compreender sua possibilidade e natureza, elucidando a carga ontológica contida no e além do conceito. Em seguida exponho as implicações embutidas na ideia de que (o) nada não existe, lidando com os aspectos paradoxais dessa conclusão. Assim, observaremos que na ideia de que não há tal coisa parecemos aceitar existir algo que não existe. Em outras palavras, ao considerarmos verdadeira uma sentença existencial negativa da forma " $\times$ não existe", como é possível dizer algo verdadeiro sobre um objeto que não é, dado que é preciso pressupor a existência do mesmo para não afirmá-lo? Como podemos afirmar a não existência de algo sem nos comprometermos com a existência desse algo que afirmamos não existir (sem elucidar um paradoxo)? Quando em nossas crenças, nosso discurso e nossas teorias, estamos comprometidos com a existência de algo?

A partir da forma lógica dessa indagação explicito por meio do paradoxo (do não ser), também conhecido (contemporaneamente) como o problema dos existenciais negativos, uma lógica contra o argumento da inexistência da inexistência. Entendimento que uma vez pensado à luz da tradição filosófica, ${ }^{5}$ i.e., Parmênides, pode ser concebido como o desenvolvimento da metafísica enquanto um processo de anulação do nada. Concepção que acaba por expor o âmago ontológico da metafísica ocidental, que, para além da impossibilidade do nada no pensar e na linguagem, demarca através da compreensão de que "tudo existe" o que aceitamos como sendo realidade, possível ou provável por não contrariar a verdade. ${ }^{6}$

Desenvolvo então um relato do relacionamento (de degradação) do Ser para com o não ser (nada), ${ }^{7}$ instaurado por um monismo paradoxal (o Ser em oposição ao não ser) e fundamentado no princípio de identidade parmenídico ("o mesmo é pensar e Ser"). Para tanto, me utilizarei de: Parmênides, Górgias e Platão. Termino o capítulo com um diagnóstico para essa teoria: sugiro que ela é composta por um erro na compreensão entre "Ser" e "existir" e que a dimensão ontológica que circunscreve um objeto não existente deve ser pensada por outro viés.

A letra maiúscula se dá pela compreensão de que estamos lidando com um nome e substantivo próprio.

5 Penso que é um problema agarrar-se a uma data como marco histórico ou o próprio termo de uma narrativa criada para estabelecer uma lógica à própria existência humana. Inicio minha averiguação em Parmênides apenas por considerar uma formulação em destaque do problema ontológico. Condição que ainda se manifesta de modo contemporâneo e culmina, como veremos, numa relação com o niilismo. É possível que anteriormente algumas formulações tenham sido tão importantes quanto, no Oriente ou Ocidente.

6 Verdade: tomarei tal termo apenas como eficácia de um procedimento cognitivo, sendo este vinculado a uma estruturação lógica. Em conformidade a uma regra axiomática, um critério formal, ao lado de um conceito de verdade, como correspondência, torna-se então uma definição da própria verdade. Pretendo assolar tal concepção durante o presente trabalho.

7 O termo "não ser" como sinônimo de "nada". Todavia, é possível conceber o não ser como oposição complementar ao Ser, indicando algo e sendo discrepante ao termo "nada". Minha perspectiva é que o não ser, tomado como sinônimo de "nada" não indica necessariamente um Ser do não ser. Não estou tomando o não ser como complementar, dado que o não ser e (o) nada não são coisa alguma (aquilo que não é). 
De outro modo, os termos "Ser", "há" e "existe" são comumente e erroneamente expressados enquanto sinonímias pelo quantificador existencial $(\exists)$, qual é, consequentemente interpretado como aquele que possui uma importância (carga) ontológica. Esses termos devem ser realocados no pensar.

No segundo capítulo, apresento quatro diretrizes para a compreensão "do" nada enquanto um objeto não existente:

1) Quais seriam as razões para pensarmos que existem objetos não existentes?

- A existência: propriedade ou quantificador?

- $\mathrm{O}$ argumento da intencionalidade - Meinong (Teoria dos objetos).

2) Caso tais objetos existam, que objetos são?

3) Como podem ser caracterizados?

- Princípio da caracterização (PC)

4) É possível elucidar uma teoria consistente dos objetos não existentes? Qual seria a força explicativa de tal teoria?

- (O noneísmo) - Towards Non-Being de Graham Priest;

- Uma semântica para reivindicações intencionais e a concepção noneista.

Segue-se, portanto, a análise de uma metafísica pautada em textos contemporâneos que se relacionam com o pensamento de Parmênides, i.e., Russell, Meinong e Priest. Estes dois últimos possibilitam auscultar critérios para uma teoria consistente.

Em princípio questiono as relações entre objetos e a existência, examinando o que significa inferir que a existência é uma propriedade ou assume (ontologicamente) segundo a perspectiva quantificacional. Todavia, será com Meinong e sua teoria da intencionalidade que aprofundo a questão (1). Ao tomar a intencionalidade como a ferramenta ou fenômeno mental que se caracteriza como um direcionamento intencional para um objeto, questiona-se que as pessoas imaginam, desejam ou temem coisas que não existem. Igualmente, apresento argumentos contra a concepção de que pensar um objeto é necessariamente pensar um objeto existente, i.e., pensar um objeto (Ser) e pensar o mesmo enquanto existente são exatamente a mesma coisa. Na questão (2), apresento categorias de objetos não existentes, personagens fictícios e um objeto metafísico como (o) nada, nosso objeto máximo numa possível hierarquia ontológica. 
Todas essas questões, uma vez vinculadas a (3), elucidam o princípio de caracterização, indicando que um objeto pode ter ou não a propriedade da existência e o fato de não tê-la não o faz inexistente (não ser). Assim, enfrentaremos a ideia de que objetos não existentes assumem propriedades. Tal problema é uma motivação para a crença na existência de objetos não existentes e será melhor desenvolvida através de uma semântica para a linguagem que nós usamos para expressar reivindicações intencionais. ${ }^{8}$ Para tanto, utilizo como base a obra Towards Non-Being de Graham Priest.

Priest procura compreender esse "colocar-se" em direção ao não ser segundo a argumentação de que estamos aprisionados numa linguagem que abarca somente o Ser. Como saída, o filósofo examina as imputações de existência e verdade segundo nosso domínio de mundos (universos discursivos). ${ }^{9}$ Através de uma semântica, desenvolvemos um elo para o abarcamento do não ser. Segue-se que lidaremos com a defesa dos objetos não existentes à luz do que Priest chama de noneísmo (quantificar objetos não existentes).

O terceiro e último capítulo se atenta aos aspectos pragmáticos ${ }^{10}$ do nada, qual assume seu ápice na forma de niilismo. Deste modo, após expor os aspectos metafísicos, lógicos e epistemológicos que circunscrevem nossa inquirição, apresento uma compreensão moral da questão. Considerando a teoria acerca dos objetos não existentes e o pensamento de Parmênides, apresento e comento a obra The essence of Nihilism de Emanuele Severino e Historia de la nada de Sergio Givone. Ambos elucidam (o) nada como condição de possibilidade para a reflexão sobre o enfraquecimento das categorias ontológicas e a mefítica estruturação do Ocidente.

Mediante o exposto, Severino e Givone compreendem que a história e a estruturação do pensamento ocidental se deu como o desdobramento de uma crise do pensamento moderno. Ao se distanciar dos preceitos parmenídicos, o Ocidente passou a valorizar o devir através de uma lógica da reparação. Por não conseguir se desvencilhar da ideia de um conhecimento certo e seguro (imutável), uma "verdade" última, o homem procura fundamentar também o conceito de devir. Uma outra perspectiva do real. Segue-se que rondada pela ideia de uma imutabilidade e do devir, concebendo o Ser como um produto do tempo, o devir é tomado como aquele se encaminha para o Ser, mas nunca se completa. E não chegando a Ser, a realidade passa a ser compreendida como o esforço para se apreender o que não indica uma apreensão última, dado que um objeto, uma vez concebido, não mais é. O Ser passa a ser tomado como um devirnada. Uma relação de criação e destruição que se manifesta como um retalho de Ser, uma oscilação do existente em meio ao que não é. A existência e, consequentemente, os mecanismos de amparo (ecos da imutabilidade: religião, filosofia, arte, ciência e tecnologia) para um proceder encontram-se subsumidos a esta concepção. O devir-nada instaura o niilismo e justifica o drama

8 Uma semântica capaz de atingir o não ser, viabilizando-o.

9 Mundos possíveis e impossíveis, além de atuais.

10 Compreendo que os aspectos pragmáticos de um objeto como (o) nada podem ser sintetizados como: Uma ideia sobre um objeto que nada mais é senão a soma das ideias de todos os efeitos imaginários atribuídos por nós a esse objeto, que passou a ter um efeito prático qualquer. 
histórico.

A isso Severino intitula como a "maior loucura": (O) nada, tomado e reconhecido enquanto um fantasma que ronda, por assim dizer, todos os âmbitos da cultura do nosso tempo, encrustado nos processos de secularização e racionalização da história ocidental. Tal condição impõe uma enorme força contra os percursos metafísicos e morais. Trata-se portanto de um espectro que circunscreve a história do pensamento e, consequentemente, do existir ocidental, i.e., da crença de que "as coisas saem do nada e recuam ao nada". A grosso modo, uma visão de que a perspectiva ocidental da realidade resultou na convicção de que existe "um" nada radical à existência que se coloca incompreensível e eminente. E pela imposição do devir nos deparamos com a ideia do mal que dá ao sistema sua dimensão histórica. Sendo o devir tomado como movimento pelo qual a "humanidade" se torna culpada e, ao mesmo tempo, não fundamentada. Igualmente, a obsessão pela imutabilidade elucida o esforço de uma fundamentação da contingência, explicitando uma noção de enfermidade existencial. Retornaremos a Parmênides, mais especificamente, realizando uma objeção contra uma possível estrutura de verdade atual a partir da incompreensão (do) nada pautado na ideia do devir, um devir-nada e um universo discursivo.

Concluo anunciando a possibilidade do não ser mediante a inferência de que este não é e não se manifesta como julgávamos, aspecto que não implica uma existência, mas explicita outra compreensão ontológica. Tal esforço se concentra no fato de que objetos não existentes podem assumir propriedades e isso não os fazem ser ou assumir um Ser. Desse modo, (o) nada se coloca como uma entidade soberana por sua própria negatividade, sendo sua propriedade basilar uma não-propriedade, ou seja, seu "Ser" (apreensão paradoxal) se manifesta somente enquanto não ser/não sendo. Noções que serão refletidas e desenvolvidas considerando os vestígios e concepções do nada na história da filosofia, suas apreensões metafísicas, lógicas e existenciais. Tão logo pretende-se anunciar a viabilidade de uma ontologia do não ser. ${ }^{11}$ A possibilidade de uma tese metafísica não necessária (não fundamentada), com isso questionamos a veracidade de que tudo é necessariamente alguma coisa. Um ditame não somente metafísico, mas capaz de ilustrar os aspectos sintomáticos de um esforço vital não fundamentado em qualquer verdade.

11 Alguns filósofos (Sergio Givone, Levinas) preferem utilizar o termo "meontologia". Uma ontologia negativa, díspare a tudo que é ou que está além do Ser. 


\section{Pressupostos}

\section{O problema: (O) nada e objetos não existentes (dois níveis de existência).}

As páginas que se seguem são dedicadas ao "nada". Mas como é possível pensar e falar sobre o que, ao que tudo indica, não existe? Como podemos lidar com uma série de afirmações que fazem sentido, mas não se referem a coisa alguma? Consideremos as afirmações abaixo:

1) Gregor Samsa ${ }^{1}$ esta escondido atrás do sofá.

2) Sísifo ${ }^{2}$ deseja subir o Monte Everest.

3) O nada não existe.

Estas são uma série de afirmações e todas elas fazem sentido, em geral. Possuem sujeito, verbo e estão gramaticalmente corretas. Todavia, qual é o seu grau de veracidade? Como pode uma afirmação ser verdadeira ou falsa se estamos a falar sobre coisas inexistentes ${ }^{3}$ Como é suposto pensarmos sobre coisas que não existem no mundo real, mas que de alguma forma parecem existir em nossas mentes?

Parte da razão pela qual conseguimos pensar, falar ou até imaginar coisas que (supostamente) não existem, ${ }^{4}$ é a linguagem. Sem a linguagem, só poderíamos nos comunicar sobre objetos físicos dado que a comunicação basear-se-ia principalmente no ato de apontar.

As palavras permitem-nos perceber conceitos e ideias mentais, mesmo que estas não correspondam a nada numa realidade empírica. ${ }^{5}$ Aqui encontramo-nos num novo reino, onde a linguagem vai de encontro com a metafísica e elucida um aparato lógico capaz de fornecer um procedimento verificável sobre o que julgamos como possível ou não. Isso significa que, de modo gradual, estamos utilizando a linguagem como possibilidade para uma abordagem e análise metafísica no intuito de compreender um objeto que foge à empiria (sensível). Então, quando falamos de objetos não existentes, rapidamente nos encontramos a falar de mundos imaginários, mundos que podem ferir nossos critérios de realidade e verdade, que se mostram impossíveis e possuem ou não, à primeira vista, uma carga ontológica inferior, ${ }^{6}$ mas que a linguagem parece atingir e conceituar nas nossas mentes.

1 Personagem fictício da obra "A metamorfose" de Franz Kafka.

2 Personagem fictício cunhado pela mitologia grega.

3 Me refiro a uma relação com o que não é em nenhum sentido, i.e., não possui, à primeira vista, um Ser. Estou falando sobre o não ser.

4 Ao longo do trabalho observaremos que é possível elucidar níveis de existência, de modo que, afirmar que algo não existe é indicar, por sua vez, outro ponto de vista ontológico. O uso do termo "supostamente" indica o esforço em não realizar, até então, um juízo ontológico, restringindo os termos "existir" e "realidade" a uma única compreensão.

5 Algumas coisas podem existir sem concretude, i.g., números.

6 Uma carga ontológica inferior em relação ao nosso mundo atual. Tal condição não exclui a possibilidade de um mundo com uma carga ontológica superior ou igual ao mundo atual. 
Igualmente, quando estamos a discutir coisas como verdade, significado e existência nestes mundos, precisamos de um conjunto de ferramentas filosóficas ligeiramente distintas, porque nestes mundos, várias vezes, se aplicam diferentes regras, que nós mesmos criamos. Dessa forma, entende-se que a estruturação de um mundo pressupõe um proceder compatível. Não está em concordância, por exemplo, falar sobre (o) nada abordando uma "ontologia pautada no Ser". 7 Assim, e.g., como não convém inquirir a natureza lógica de um círculo-quadrado considerando o princípio da não contradição. ${ }^{8}$

Estamos a lidar com regras que possibilitam, nos mundos que imaginamos, vida noutros planetas, ou o passado, como o conhecemos, pode nunca ter acontecido; ou simplesmente as leis da física não existem. Podemos criar universos inteiros apenas com as nossas mentes e, consequentemente, tais universos assumem diferentes formas, estruturações e valorações.

Entretanto, sobre objetos e suas existências, como denotar o que aparentemente não pode ser denotado? Compreendamos que quando começamos a lidar com o mobiliário da linguagem, uma primeira concepção a ser elucidada é a noção de referente ou referência. Este elemento, ou de outro modo, o referente de uma palavra, pode ser compreendido como o objeto no mundo a que a palavra se refere, ou à qual se liga. Por isso, o referente da palavra "mesa" ou a sentença "a mesa mais próxima a você" diz respeito a uma peça de mobília que provavelmente estamos a usar como apoio no momento da leitura deste trabalho. Ou de outro modo, um objeto físico composto de uma estrutura horizontal assentada em uma ou mais pernas (e que é a mais próxima a nós). Concebemos e apreendemos um conceito e assim discernimos o que é ou não uma mesa (próxima).

Por esta via, acessamos o nosso mundo. No entanto, se estamos a tratar sobre o que não está em mundo nenhum, ${ }^{9}$ ou seja, coisas que não se referem a nada e assinalam um não ser, o que acontece? Como podemos determinar a veracidade (do) nada ou até mesmo compreendê-lo enquanto objeto sendo que este não se refere a coisa alguma e uma vez pensado até sua essência nos retira da sua própria essência? A situação é de incerteza e precariedade.

Uma primeira dificuldade é entender porque se afirma que algo inexistente é um objeto. Afinal, se ele não é coisa alguma, como pode ser apontado como sendo alguma coisa? Neste caso, o termo "objeto" ou "coisa" se coloca como algo que assume propriedades e, por assumi-las, satisfaz certos predicados que denotam as propriedades em questão, fazendo com que as frases correspondentes assumam um valor de verdade. Nesse sentido, podemos categorizar objetos não inexistentes.

7 Pleonasmo. É sabido que o termo “ontologia” se trata do estudo sobre o Ser, assim sendo, é pautada no e somente no Ser. Veremos que é possível repensar seu conceito, desenvolvendo uma ontologia negativa, i.e, pautada no não ser, no que não é o Ser, completamente fora ou além do Ser.

8 Segundo a lógica proposicional clássica: Seja A uma sentença, (PNC) afirma que $\neg(\mathrm{A} \wedge \neg \mathrm{A})$.

9 Se estamos abordando algo sobre algo, esse algo de alguma forma reside sobre algo. Portanto, uma objeção seria afirmar que, se estamos a falar sobre objetos (existentes ou não), é porque talvez estejam em algum mundo (possível ou impossível). 
É por isso que quando nos referimos a estes, parece que simplesmente estamos a dizer coisas sem sentido, e ainda sim, numa espécie de esquizofrenia, aceitamos e parecemos acreditar saber o suficiente sobre (coisas) irreais, considerando tais informações como fatos. Juízo que ocorre pela crença de que suas propriedades são ontologicamente carregadas, ou seja, parecem pressupor uma concretude.

Ora, sabe-se que na obra "A metamorfose" de Franz Kafka, o personagem Gregor Samsa acorda e se vê transformado num terrível inseto (semelhante a uma barata). Contudo, se me dissessem que ao acordar ele se viu um morcego, saberíamos que seria uma afirmação falsa. Mas onde está Gregor Samsa no mundo real e como sei que ele é de fato uma barata e não um morcego? Como posso recusar a veracidade dessa informação sendo que ela se refere a algo que não existe? ${ }^{10}$

Dada a questão, Russell ${ }^{11}$ considera um enunciado da forma: "O planeta Vulcano está escondido entre Mercúrio e o Sol”. ${ }^{12}$ Verdadeiro ou falso? Para Russell esta afirmação se coloca como falsa apesar dessa mesma frase conter várias afirmações, ou seja, que há um planeta e que ele está entre Mercúrio e o Sol. O que torna esta sentença falsa se ela parece fazer sentido? Nesta ocasião sabemos bem que, "Vulcano" foi um planeta hipotético que se pensava existir na órbita entre Mercúrio e o Sol. Atualmente, sabe-se que tal planeta não existe. E não sendo o caso, não podemos fazer nenhuma declaração sobre.

Assim, Russell argumenta que seria tão falso enunciar que há um planeta chamado "Vulcano", orbitando entre Mercúrio e o Sol, quanto afirmar que não há. O rigor da questão indica que não se pode falar sobre o que não é. Esse planeta, é uma entidade inexistente a quem foi erroneamente atribuída existência através de um erro na percepção da língua. Circunstância que acaba por indicar também uma primeira alternativa referente à sentenças sobre objetos e suas existências, ou seja, afirmar algo sobre algo parece não indicar necessariamente que esse algo exista, seja real e verdadeiro. Podemos falar sobre algo que pode ser e não existir, com sentido ou não. Tão semelhante quanto, caso levantemos a questão da natureza da realidade, acessamos o que parece "justificar" a presença (do) nada no mundo.

Ao afirmarmos que "todos as baratas do mundo tem mais antenas do que barata nenhuma", podemos interpretar de forma significativa que há uma "barata-nenhuma" i.e., uma "não-barata". Contudo, sabemos o que e como são baratas, que elas simplesmente existem ou não. Não pensamos uma "não-barata" (em complemento ao que é) para indicar a existência de uma barata, ou até mesmo empiricamente, não seria possível ver uma não-barata. ${ }^{13}$ Esta conclusão,

\footnotetext{
10 Ainda aqui evito um juízo ontológico. Não estou inferindo o que existe ou não existe de fato. Uma resposta possível seria assumir um critério de existência mais amplo, que não tomasse como verdade última uma existência restrita ao âmbito empírico. Desenvolvo tal argumentação nas próximas páginas.

11 RUSSELL, B. On denoting. Mind, v. 114, n. 456, p. 480-493, 1905. Em suma, Russell aborda a possibilidade de se denotar algo que não denota nada.

12 O exemplo utilizado por Russell é: “O atual rei da França é careca”. A minha mudança não gera uma diferença teórica na conclusão.

13 Mais adiante apresento a perspectiva platônica que enaltece o não ser como alteridade, uma possível saída para a
} 
tal como a ideia de um planeta (Vulcano), é uma peculiaridade da nossa linguagem que acaba por tornar um/o "nada" em algo. Aspecto que como veremos, desencadeia toda uma compreensão ocidental acerca do enfraquecimento ou destruição das categorias ontológicas, culminando no niilismo, a crença de que as coisas vêm do nada e retornam ao nada.

Mediante o exposto, Russell tinha certeza que não era possível fazermos afirmações com sentido sobre o que não existe. Posição que pode ser contraposta com Alexius Meinong, um filósofo austríaco do século XX e que tinha uma opinião diferente. Meinong ${ }^{14}$ estava convencido de que podemos ter pensamentos com significado sobre objetos que não existem enquanto concretude. Mas, disse ele, para que possamos dizer algo com sentido sobre alguma coisa é preciso que, de alguma forma, essa coisa "exista" (esteja de acordo com certas condições), justificando a existência de objetos não existentes. Para isso ter sentido, precisamos realocar nossos critérios de existência, ou melhor, considerar dois níveis de existência e respectivamente sua carga ontológica. Assim, Meinong ${ }^{15}$ desenvolve uma ontologia, ou seja, um sistema de existência que foi dividido em três classes: "absistência" (Gegebenheit), ${ }^{16}$ subsistência (Bestand) e existência (Existenz). Postulando que até mesmo coisas inexistentes assumiriam uma posição nesta estruturação. ${ }^{17}$

Ocorre, portanto, que qualquer objeto que se possa imaginar, "absiste". Se podemos pensar sobre esse algo, de alguma coisa "absiste". Isso inclui, portanto, coisas que nunca existiram no mundo a que temos acesso, coisas que não existem e talvez nunca existam de fato, i.e., unicórnios, a Medusa, Sísifo, Gregor Samsa, (o) nada, a paz mundial, etc. Secundariamente, dentro do grupo de coisas que "absistem", há um subconjunto de objetos subsistentes. Estes seriam coisas como números e teoremas, que não manifestam uma existência física, mas também não contêm nenhuma impossibilidade. Números apenas não são coisas físicas ${ }^{18}$ e por isso não podem ser encontrados em parte alguma. Por fim, objetos existentes são aqueles que se encontram aqui, no mundo físico (atual). Seriam alguns exemplos: Carros, cachorros, livros, o atual presidente do Brasil, a torre Eiffel, entre outros. Objetos que, uma vez possíveis, assumem três níveis de existência segundo o arcabouço meinonginiano: existem, podem ser conceituados

minha argumentação. Nesse sentido, tudo que não é se dá por ser um algo-outro. Assim, podemos afirmar que tudo que não é uma barata é uma não-barata.

14 MEINONG, A. The theory of objects. In: Realism and the Background of Phenomenology. [S.1.]: The Free Press, 1960. cap. 4, p. 76-117.

15 (ibid.)

16 O termo Gegebenheit pode ser compreendido, a grosso modo, pelo termo ser-dado, Segundo Meinong, esse termo infere que podemos denotar um objeto ainda que este não possua um Ser. Ao ser traduzido para a língua inglesa, temos "Absistence" no sentido de "everything absists" (tudo absiste), não havendo tradução para o português. Optei por manter uma palavra semelhante à original apenas para facilitar o entendimento.

17 MEINONG, Alexius. Sobre a teoria do objeto. In: BRAIDA, Celso R. Três Aberturas em Ontologia: Frege, Twardowski e Meinong. Florianópolis: Rocca Brayde, 2005. p. 91-145.

18 ... mas representam coisas físicas. Um número pode ser compreendido como uma extensão de predicados, sendo sempre atribuídos a extensões; exemplo: o número "2" é uma propriedade comum pertencente a toda extensão que tem dois membros/elementos. Deste modo, números são extensões de segundo grau. Dito isto, podemos afirmar que números se aplicam a coleções de coisas e não tão explicitamente à coisas. Para mais informações, consultar bibliografia: Frege e Jairo José da Silva. 
e podem ser imaginados. ${ }^{19}$ Pensamento que foi intitulado como "a selva de Meinong" - um lugar onde seria possível um quadrado-redondo, um planeta (Vulcano) entre Mercúrio e o Sol, a Medusa, unicórnios, um Sísifo feliz, (o) nada e qualquer outro objeto não existente; (de acordo com o critério de existência enquanto concretude) que ali poderia (não) residir. Portanto, pela teoria de Meinong podemos diferenciar objetos (atuais e existentes) de objetos não existentes e até mesmo objetos não existentes entre si (dada suas propriedades). Estabelecendo uma possível diferença entre um quadrado-redondo e uma coisa como Gregor Samsa, Sísifo e (o) nada. E se de algum modo consideramos os nomes Gregor Samsa e Sísifo, estabelecemos também uma espécie de relação do sentir com tais objetos. Relação que parece não ter sentido uma vez pensada juntamente à ideia da existência do não existente, ou em última instância, de um nada, i.e., o nada enquanto algo. ${ }^{20}$

Por este contexto, como compreender a manifestação do nada como um fenômeno metafísico, lógico e existencial? O que é (o) nada? Um objeto não existente, mas dotado de propriedades? Caso sim, que propriedades assume? Podemos falar sobre (o)/(do) nada? As páginas que se seguem esmiúçam a dificuldade de uma caracterização pertinente.

\title{
1.1 O Ser e o não ser (Parmênides)
}

\author{
O que não sei fazer desmancho em frases \\ Eu fiz o nada aparecer. \\ (Represente que o homem é um poço escuro \\ Aqui de cima não se vê nada. \\ Mas quando se chega ao fundo do poço já se pode ver o nada. \\ Perder o nada é um empobrecimento. \\ (Manoel de Barros, Livro Sobre Nada, p. 63)
}

Será que alguma vez (o) nada existiu? Questionar (o) nada é pensar sobre o começo e o fim de todas as coisas? Não se tratando de um mero problema linguístico, mas também metafísico, inquirir (o) nada, tomando o mesmo como algo, é lidar com uma análise da linguagem enquanto procedimento de acesso a esse objeto para que, consequentemente, seja possível explorar sua constituição.

Por uma breve reflexão, podemos examinar a questão. Em primeiro lugar, se concebemos as coisas enquanto inseridas no devir, tudo muda, nada é - todavia, anterior ao tempo

19 MEINONG, Alexius. Sobre a teoria do objeto. In: BRAIDA, Celso R. Três Aberturas em Ontologia: Frege, Twardowski e Meinong. Florianópolis: Rocca Brayde, 2005. p. 91-145.

20 (O) Nada enquanto algo e a dificuldade de compreendê-lo. Neste momento surge problema: o que antes poderia ser o vazio da existência, aquele como qual um dia pôde suportar elementos "reais" e que hoje se encontram ausentes; pelo sentimento "do" nada encontramos a aniquilação de toda e qualquer possibilidade de um elemento ou mecanismo de amparo ao existir humano. Não há sequer a ideação do vazio. Uma vez que o nada passa a residir no coração de tudo que é, tal objeto é tomado como uma espécie de secreção do Ser, fazendo que tudo passe a ser tomado pela noção de que é e sempre será nada, ausência e insignificância eterna. 
mesmo, o tempo não existia? Logo, existia algo que não existia? Existia (um) nada? Consequentemente, se nada poderia vir a acontecer, o que e por que algo aconteceu? Prima Facie, uma razão se faz necessária. E qual seria a probabilidade (do) nada continuar a ser nada ou vir a Ser? Seria possível que coisa nenhuma viesse a ser alguma coisa? Pensar o nada é também pensar o Ser e pensar o Ser é também pensar o devir? Se o existir pode indicar o padecer diante do possível, a ideia de (um) nada elabora um tempo morto, explicitando o abandono à asfixia do Ser (ou do devir)? Tantas indagações nos levam a um emaranhado de questões que dizem respeito ao âmago da filosofia e do existir humano.

Em segundo lugar, se é possível indicar que por um problema linguístico acabamos desenvolvendo a crença de que (o) nada é algo, sua manifestação elucida um esforço admissível: é possível pensar sobre tal objeto. Foi assim que alguns filósofos buscaram compreender tal incômodo. Em conformidade, a grosso modo, para Heidegger, (o) nada emerge pela angústia; ${ }^{21}$ segundo Sartre, ${ }^{22}$ pela não fundamentação da consciência, para Leibniz, ${ }^{23}$ um problema de fundamentação ontológica (teológica); todavia, permanecendo a robusteza da questão. Não seria (o) nada gerado também pela incapacidade de uma caracterização pertinente daquele que o concebe se colocando, por fim, como causa para um desconforto? Se sua apreensão e fundamentação proclama a inviabilidade de si mesmo, o que a linguagem parece não atingir assume como télos um pathos negativo? Por que razão (o) nada é impedido ao pensar? Convém compreender como se deu a restrição (do) nada.

Para tanto, uma importante distinção ontológica se fez na história da filosofia e pode ser acusada como condição para este entrave, ou seja, aquela qual justifica a impossibilidade de compreender um objeto não existente e tão superior como (o) nada (não ser). Sob este prisma, têm-se que um dos primeiros filósofos a reivindica-lo enquanto categoria filosófica foi Parmênides de Eleia, qual proclamou sua (não) ${ }^{24}$ paternidade sobre o inexistente, fazendo com que o nada, desde então, se fizesse presente, mas inferiorizado e inalcançável.

Neste contexto emerge uma primeira concepção do nada (enquanto não ser) no pensamento filosófico, em absoluta oposição ao Ser. Uma primitiva compreensão ontológica no intuito de estabelecer uma caracterização pertinente do pensar e do real. Assim, Parmênides infere $^{25}$ que o Ser é e o não ser não é, sendo que o pensar é tomado como aquele que busca acessar algo, indicando o real, ou seja, apenas o que é possível Ser.

${ }^{21}$ HEIDEGGER, Martin. Que é metafísica? In: Os pensadores. "p.40-45” São Paulo: Nova Cultural, 1999.

22 SARTRE, Jean Paul. O Ser e o Nada: Ensaio de Ontologia Fenomenológica. $11^{\circ}$ Trad. Paulo Perdição, Petrópolis: Vozes, 2002.

23 LEIBNIZ, G.W. Monadologia e outros textos, A. Organização e tradução de Fernando Luiz Barreto Gallas e Souza). São Paulo: Hedra, 2009.

24 Parmênides reivindica (o) nada enquanto um objeto não possível. Ao afirmar que o Ser é e o não ser não é, o filósofo se atenta somente ao Ser, negando a realidade (do) nada e por conseguinte impossibilitando uma ontologia do não ser. Por isso podemos afirmar que Parmênides foi um dos primeiros filósofos a se referir e estimular o campo teórico (do) nada, todavia, inviabilizando-o.

25 PARMÊNIDES. Da natureza. Edição bilíngue. Tradução e comentário de José Trindade Santos. São Paulo: Loyola, 2009. 
Esse algo que se mostra, por Ser, existe. Ao contrário, acessar o que não é seria simplesmente tentar se relacionar e acessar (o) nada (inexistente/não ser). Então, uma vez que Parmênides vincula o pensar e o real ao Ser, (o) nada é recusado por nada ser e indicar um falso caminho. A verdade só pode ser atingida pelo pensar, que se estrutura somente através do que é.

Então, logicamente, podemos elucidar uma primeira caracterização (do) nada pautada numa linguagem de $1 .^{\circ}$ ordem (L1), ou seja, a partir da linguagem de um cálculo quantificacional podemos compreender a inviabilidade (do) nada no pensamento parmenídico. Considere a linguagem quantificacional:

- $\exists$ (Quantificador existencial);

- $\neg$ (Negação);

- $\wedge$ (Conjunção);

- × (Variável).

Ao considerarmos os conectivos tomados como parte de uma (L1) e consequentemente subsumido aos princípios básicos da lógica, ${ }^{26}$ temos que uma caracterização pertinente deve obedecer tais princípios; sendo de extrema importância para considerar um raciocínio válido ou não, imputando verdade ao objeto em questão. Por considerarmos uma variável para objetos, nos ocorre que existe um $\times$, assim podemos apontar a captura de um objeto através do quantificador existencial $(\exists x)$. O quantificador $(\exists)$ enriquece a noção de captura de um objeto, sendo ele mais abrangente para discursos sobre o Ser. Todavia, se estamos a falar de um objeto como (o) nada (tomando $X=$ "nada"), consideramos que o quantificador existencial indica a existência do nada $(\exists x)$, o que nos parece absurdo. Por outro lado, afirmar que "o" nada não existe é afirmar que existe algo que não existe (existe um $\times$ que não existe), que é uma contradição.

A isso chamaremos de paradoxo ${ }^{27}$ do não ser ou o problema dos existenciais negativos. ${ }^{28}$ De outro modo, isso significa que pela presença do quantificador existencial $(\exists)$, caso tenhamos um enunciado como "O nada não é" ou "O nada não existe", traduzido como $(\neg \exists x)$ sendo ( $\mathrm{x}=$ nada), estamos a afirmar que existe um objeto $(\exists \mathrm{x})$ que não existe. Consequência lógica que fere nossos critérios de realidade, indicando que, considerando Parmênides, há somente uma realidade possível.

Essa lógica é responsável pela estruturação de todo pensamento lógico clássico que, posteriormente, se firmou como (L1), sob o princípio da não contradição, do terceiro excluído e

26 Princípio da não contradição, princípio da identidade e princípio do terceiro excluído.

27 Uma declaração que indica verdade, todavia, leva a uma contradição lógica. Fonte: ABBAGNANO, Nicola. Dicionário de filosofia. 6. éd. São Paulo: WMF Martin Fontes, 2012. p.864-865.

28 Tais termos não foram cunhados pela minha pessoa. O entendimento e a denominação de ambos se deu a partir de um processo histórico do filosofar. 
da identidade (formal). ${ }^{29}$ Por indicar a veracidade ou falsidade de algo, um raciocínio pautado nesses princípios passa a reger as nossas inferências e imputações de verdade. Um proceder epistêmico, mas também uma estagnação ontológica, inviabilizando também a compreensão sobre a existência de objetos não existentes. Trata-se de uma questão que perpassou toda a história da filosofia e se colocou como um mecanismo de anulação do nada.

Por isso, nossa inquirição procede a partir do questionamento desses princípios, nos levando a duas colocações que se mostram essenciais:

(1) Por criarmos mundos pautados em regras que muitas vezes fogem ao pensar, essas regras, assumindo uma semântica, possuem também uma profundidade metafísica. Aspecto que, de modo introdutório, nos ajuda a compreender nossa relação com uma categoria de objetos não existentes.

(2) Então, se (o) nada se coloca como um objeto não existente sequer passível de conceituação e representação, seu conceito foge a si mesmo. Seria possível uma semântica que suporte o não ser, fora de (L1)? Nos restando apenas seu paradoxo, como fundamentar sua verdade lógica para que seja possível, por conseguinte, fundamentar uma ontologia do não ser?

O capítulo que se segue, pautado na noção de objetos não existentes e orbitando sobre o conceito de "nada", busca compreender a ontologia de Parmênides e suas implicações. Condição que acabou por despertar (o) nada, tornando-o tão incompreensível a ponto de fazer a precariedade do Ser perante a concepção de uma ausência absoluta se converter na angústia do existir.

\subsection{O paradoxo do não ser (existenciais negativos)}

\section{Tudo existe ou (o) nada existe? A discrepância entre ser e existir.}

Parmênides pode ser acusado, a grosso modo, como o responsável por enfatizar (o) nada (não ser) como irrealizável. E se aqui buscamos indagar e compreender a realidade de um objeto não existente, (o) nada e suas implicações, convém também questionar os pressupostos que indicam sua inviabilidade. É em seu poema "Sobre a natureza" que Parmênides argumenta sobre a impossibilidade de se falar e pensar sobre o que não é:

\footnotetext{
"Vamos lá! - eu interrogarei, tu porém, auscultando a palavra, cuida que caminhos únicos do procurar são dignos de serem pensados: um, que é e que não-ser não é; é o caminho da obediência, (pois segue o desvelar-se). O outro, que não é, e que necessariamente não-ser é; este caminho eu te digo em verdade ser totalmente insondável como algo inviável; pois não haverias de conhecer o não-ente (pois este não pode ser realizado) nem haverias de trazê-lo a fala" (Parmênides, Sobre a natureza, fr.2.).
}

Parmênides usou do raciocínio dedutivo de modo a revelar a verdadeira natureza

29 Princípio da identidade: Seja " $\alpha$ ” um objeto. Logo, “ $\alpha$ ” = “ $\alpha$ ”. 
física do cosmos. O eleata argumenta para provar que tudo que aprendemos com os sentidos é falso. Ao iniciar sua argumentação, Parmênides pensa o "Ser", que segundo ele, contém todas as coisas, dizíveis e pensáveis. Isso significa que ainda que algumas coisas não existam no mundo, elas são, pois, podemos concebê-las. Esse conjunto por conter todas as coisas, faz com que o conjunto complementar, o "não ser”, não faça sentido e seja inconcebível. Sendo assim, para Parmênides, o Ser é e o não ser não é. ${ }^{30} E$ se não há nada além do Ser, pois, tudo que existe é, e tudo que não existe não é, devemos concluir que ele é único (1), não há nada além do Ser no espaço ou no tempo. Por ser único, não faz sentido que pensemos em divisões dado que só possa haver divisões quando algo diferente da coisa faz barreira entre as duas partes. Portanto, uma linha de Ser no meio do Ser, da mesma forma, não vai dividir nada. E uma linha de algo que não seja o Ser também não faz sentido, pois, como concluímos, o Ser é único. Sendo assim, o Ser é indivisível. ${ }^{31}$

Além disso, se não há nada além do Ser, ele não pode se transformar em nenhuma outra coisa, mudar significa se transformar em algo diferente de si mesmo, o que indicaria uma contradição. Não é possível mudar e continuar o mesmo. Por não haver outro além do Ser, ele não pode se transformar em nenhuma outra coisa, levando Parmênides a concluir também que o Ser é imutável (2). Condição que uma vez elucidada, nos leva a compreender o "Ser" também como onipresente, já que qualquer descontinuidade na sua presença seria indicar a existência do seu oposto, o "não ser".

Uma vez que seu movimento indicaria um poder vir a ser algo novo, então seria e não seria ao mesmo tempo, o que (para Parmênides) não é possível. Portanto, se todo espaço está dentro do "Ser" que não muda e não tem partes que possam se alternarem entre si, não há onde ocorrer algum movimento, ou seja, o "Ser" é também imóvel e eterno (3).

Por esta compreensão, Parmênides conclui: pelo mundo ser logicamente imutável, diferente do que se manifesta a nós (mutável), apenas podemos inferir que este só pode ser falso, não passando de uma ilusão. Deste modo, atingimos a compreensão de que os caminhos da verdade seriam aqueles trilhados pelo pensar. Tal conclusão, ao evidenciar o Ser como a verdadeira realidade, imutável e eterna unidade (incapaz de suportar contradições), destaca a primazia de uma fundamentação que se mostra contrária ao mobilismo heraclitiano e ao dualismo pitagórico. Elaborando uma primeira estruturação lógica sobre o que é.

Resumindo, Parmênides se opõe à Heráclito ${ }^{32}$ que concebe a realidade como um fluxo permanente, tudo flui e tudo se move, exceto o próprio movimento. Assim sendo, tudo é concebido como devir, sendo este, um princípio, ou seja: $O$ ser é tão pouco como o nãoser; o devir é e também não é. As determinações absolutamente opostas estão ligadas numa

30 Doxografia e crítica moderna: NIETZSCHE, F. Os Pré-Socráticos, Parmênides de Eléia: . In: "Os pensadores". Trad. de Carlos A.R. de Moura. São Paulo: Nova Cultural, 2000.

31 (ibid).

32 HEGEL, Georg W.F. Pré-Socráticos, Os. Heráclito de Éfeso. In: “Os pensadores”. Trad. de Ernildo Stein. São Paulo: Nova Cultural, 2000. p.103. 
unidade. ${ }^{33}$ Nada permanece idêntico a si mesmo. Com isso, todas as coisas que existem só existem enquanto uma relação com seu oposto, o que é só é por ser um não-outro. Não obstante, Pitágoras, também diverso à Parmênides, se concentra na ideia de que assim como os números se compõem da soma de pares e ímpares, as coisas também encerram determinações opostas, como as de "limitado" e "ilimitado" (ser e não ser, cheio e vazio), resultando que toda a realidade é vista como uma conciliação de opostos. ${ }^{34}$ Pela recusa de ambos, Parmênides se atenta ao fato de que se a mobilidade pode pressupor a verdadeira realidade, esta não pode ser apreendida, pois, uma vez concebida, ela não mais é. Da mesma forma, uma conciliação de opostos, como também propõe Pitágoras, legitimaria a existência do não ser, fazendo o que não é, Ser.

Acrescenta-se, portanto, que nada foge ao pensar, dado que uma vez pensado, se torna parte do pensamento, ainda que carente de uma representação possível. E se nada foge ao pensar, uma vez pensado, é. Por esta compreensão Parmênides fixa o Princípio da Identidade (PI): ${ }^{35}$ "pois o mesmo é pensar e Ser". ${ }^{36}$ O que pode ser apreendido é a verdadeira realidade daquilo que se mostra. À vista disso, pensar se coloca necessariamente como "ocupar-se" de entes, ${ }^{37}$ colocar-se em direção ao Ser, assumindo o Ser mesmo. Concepção que, caso levada até seu limite, se mostra problemática - estamos a afirmar que tudo existe, tudo é.

Frente a este cenário, o princípio da identidade (PI) acaba por elucidar um primeiro traço da metafísica ocidental, esta não somente vinculada a Physis, mas assumindo na ontologia ${ }^{38}$ um primeiro traço de metodologia também regrada no $\lambda o ́$ yos (discurso). Busca-se então pensar e exprimir apenas o Ser através de uma inquirição, que se coloca, em última instância, semânticoontológica. Lidando com os limites de validação do próprio raciocínio. Ponto que justifica a inviabilidade do não ser enquanto um objeto a ser conhecido e proferido (pois este não pode ser realizado). Todavia, ainda não é claro o que Parmênides entende por "existir" ou simplesmente "existe". Prima facie, tais termos se colocam apenas como uma delimitação ou definição de Ser. E se o Ser admite necessariamente a existência, ao pensarmos em coisas como Sísifo, Medusa ou em última instância, (o) nada, não temos um real indicativo de que estes objetos existam no mundo. Se pensar pressupõe um existir, estes objetos deveriam existir no nosso mundo e só assim seria possível apreendê-los, o que não é o caso.

Consideremos dois usos ${ }^{39}$ para a delimitação do termo "Ser" no intuito de estabelecer

33 (ibid).

34 NIETZSCHE, F. Pré-Socráticos, Os. Pitágoras de Samos: . In: “Os pensadores”. Trad. de Rubens Rodrigues Torres Filhos. São Paulo: Nova Cultural, 2000.

35 Não confundir com o princípio de identidade de uma lógica de primeira ordem. O princípio de identidade formal indica que $\forall x(x=x)$, No caso de Parmênides, (PI) apenas indica que "pensar é o mesmo que ser".

36 ... pois o mesmo é pensar e ser. (III, P.45 - PARMÊNIDES, Da natureza. Edição bilíngue. Tradução e comentário de José Trindade Santos. São Paulo: Loyola, 2009).

37 O que é, em qualquer dos significados existenciais de Ser. Em suma, Parmênides reduz o ente ao ser e, consequentemente, como algo existente, este que é possível enquanto abarcado pelo pensar. Nessa perspectiva, o ente impõe o existente.

38 Ciência acerca do ser enquanto ser: Doutrina do ser e das suas formas. ABBAGNANO, Nicola. Dicionário de filosofia. 6. éd. São Paulo: WMF Martin Fontes, 2012. p.848.

39 Embora nem sempre formulada, essa distinção é assumida ou pressuposta quase universalmente. 
uma melhor compreensão do PI:

1) Uso predicativo, em virtude do qual dizemos: "Sócrates é homem", ou "a rosa é vermelha".

2) Uso existencial, em virtude do qual dizemos: "Sócrates é" (= existe), ou "A rosa é" (= existe).

A importância desta distinção é um problema profundo e também ambíguo, capaz de produzir na literatura muito mais que problemas linguísticos, assumindo pragmaticamente uma valoração do real como um procedimento duvidoso sobre o colocar-se no mundo. A dificuldade em elucidar o que é ou não é pode nos levar a um colapso epistemológico culminando, por exemplo, na ideia do nada como sendo algo. Capaz de atingir o existir e estimular o niilismo. ${ }^{40}$ Por tais perspectivas, consolidam-se compreensões, especialmente na filosofia e nas diferentes formas de captar o mundo, desde a antiguidade até os dias atuais, atingindo também a teologia. Essa dificuldade ocorre pelo significado predicativo em Parmênides ser confundido com o indicativo existencial. O uso predicativo, uma vez atribuído ao Ser, pode ser distinguido em mais três doutrinas fundamentais: ${ }^{41}$

A) Inerência;

B) Identidade (ou suposição);

C) Relação.

A primeira apresentação (A) pode ser compreendida pela sentença "Sócrates é homem", resultando que (S) - Sócrates - inere a (essência) homem ou "a rosa é vermelha", que "R" (rosa) pertence à qualidade de vermelho. ${ }^{42}$

Adiante, (B) elucida a interpretação fundamental de Ser predicativo enquanto identidade de um objeto no qual o sujeito e o predicado da proposição se referem ou indicam no lugar do qual estão. Assim, "Sócrates é homem" indica através da cópula que o sujeito "Sócrates" e o predicado "homem" se referem ao mesmo objeto existente e que, portanto, pode ser qualificado com um ou com o outro dos dois termos, enaltecendo uma unicidade. ${ }^{43}$

Por (C) entendemos relações entre coisas e entre fatos, podendo ser também relações entre proposições. Tal relação, expressa pela cópula, é a mesma em todas as formas proposicionais, não porque sua natureza esteja expressa na proposição, mas porque é estabelecida por convenção. Isso possibilita uma compreensão entre coisas e fatos, imputando o que chama-

40 Desenvolveremos uma melhor compreensão sobre o que entendo por "niilismo" no último capítulo. No momento, convém apenas esclarecer o que é (o) nada (um objeto não existente) e sua relação com a predicação.

41 A argumentação e a distinção que se segue foi toda pautada na compreensão do termo "Ser", presente em: ABBAGNANO, N. Dicionário de Filosofia - São Paulo, Martins Fontes. 2012. p.1043-1045 (Ser).

42 (ibid).

43 (ibid). 
mos de "real" e indicativo de um conhecimento segundo o alcance de proposições tidas como verossímeis. ${ }^{44}$

Mediante estas considerações, podemos concluir que Parmênides toma o Ser apenas como indicativo existencial (2), sendo inerente (A) ao que é, ou seja (2A). E ainda que seus fragmentos não sejam explicitamente claros, sua argumentação deixa a entender que o termo "existir" ou "existe" se refere ao modo de ser determinado ou determinável cujas propriedades implicam o modo de ser "real" ou de fato, constituindo uma unidade, permanente e imóvel. Portanto, se a apreensão de um objeto torna um objeto possível, ou seja, existente, o que é (o) nada a que me refiro? Se pensar um objeto resulta que o mesmo exista (Ser), temos um problema ontológico. É preciso manter uma separação entre modos de existência. Ao que tudo indica, o conceito de um objeto não inclui necessariamente o conceito de existência.

Por esta estruturação, Parmênides pode ser apontado como um dos primeiros de uma longa lista de pensadores a defender a tese de que tudo existe. Assim, se nossas imputações de verdade e fundamentação encontram-se mediadas pela linguagem, cabe compreender a estruturação da mesma como mecanismo para a possibilidade de um raciocínio válido ou possível. Se é pela aceitação dessa proposição (PI/Tudo existe) que aniquilamos o nada e, por conseguinte, se não podemos falar sobre o que não é, como lidar com um objeto metafísico como o não ser? Persistir no nada é ser contra uma letargia ontológica.

Um primeiro passo é aceitar que o Ser enquanto uso predicativo ou indicativo de existência parece não indicar uma existência atual. Não devemos tomar os termos "Ser", "há" e "existe" enquanto sinônimos. E aqui acessamos um novo mundo, onde algumas coisas podem ser, mas não existir. Por este breve argumento viabilizamos a existência de objetos não existentes. ${ }^{45}$

Foi nesse sentido que, ${ }^{46}$ ainda no período clássico, contestando o Eleata, Górgias radicaliza seu pensamento e o (ataca) no contexto da sofística. Recusando o princípio de identidade (PI: o mesmo é pensar e ser) e opondo-se a uma noção de verdade positiva e absoluta, Górgias infere que "nada existe". Mas aqui não se trata do objeto "nada" e sim a aniquilação do Ser e de uma possível epistemologia.

A argumentação e conduta de Górgias pode ser vista a partir de três aspectos basilares, como explana Barbara Cassin: ${ }^{47}$ "Nada, diz ele, é; mas se é, é incognoscível; e se é e é cognoscível, não é, no entanto, mostrável aos outros"(P.197,2015). O que aqui está fundamentado, em última instância, ocorre pelo fato de que para Górgias, tanto a unicidade do Ser de Parmênides e a multiplicidade de Heráclito acabam por apresentar contradições em si, ao serem contrapostas. Ao considerar as duas concepções de Ser como verdadeiras e assumindo que estas duas premissas, opostas entre si, se anulam, caso julguemos ambos os argumentos, a própria

44 (ibid).

45 Este argumento será melhor desenvolvido no capítulo II.

46 Uma breve digressão apenas para apresentar duas compreensões antagônicas à Parmênides.

47 CASSIN, Bárbara. Se Parmênides, O tratado anônimo de Melisso Xenophane Górgias, São Paulo: Autêntica, 2015. 
veracidade de ambas é colocada em dúvida. Assim sendo, duas premissas concebidas como verdadeiras e antagônicas que buscam elucidar uma mesma conclusão (a veracidade do Ser), ao se anularem, apenas esclarecem que a concepção de Ser proposta por ambos esta equivocada.

Górgias pode então dizer que ou o Ser não é o que pensava ser ou não existe. Igualmente, por esta lógica, Barbara Cassin conclui: “[... ] o não ser é, o ser, diz ele, seu oposto, não é. Com efeito, se o não-ser é, convém que o Ser não seja (P.199, 2015)". 48 E assim Górgias conclui que "nada existe".

Saída buscada por Platão, que numa espécie de parricídio renega Parmênides e seu monismo paradoxal segundo a tese de que: dizer o não ser é apontá-lo como constitutivo daquilo que é. Afirmar que um (objeto) não é seria o mesmo que inferir que ele é algo, ou seja, um algo-outro (não ser $X$ indica que seu não ser ocorre por este objeto ser outro, i.e., Y). ${ }^{49}$ Isto significa que afirmar o não ser é apontá-lo como sendo tão fundante quanto o que diz o Ser. Dizer o não ser é dizer algo sobre algo. Deste modo, o não ser também é e se o não ser não fosse, seria de fato incognoscível e incomunicável.

Em síntese, Górgias coloca o Ser e o não ser em uma espécie de equivalência negativa, recusando a profundidade metafísica do que significa apreender algo. Com isso, o sofista aniquila a possibilidade de um conhecimento verdadeiro. Platão, no que lhe concerne, busca mediar o monismo paradoxal imposto por Parmênides, trazendo a luz uma nova categoria onto-dialética onde a harmonia se dá pela relação entre opostos indicando uma unidade real. ${ }^{50} \mathrm{Em}$ suma, uma negação completa da ontologia de Parmênides o Ser e não ser conciliados.

A estratégia parmenídica pode ser então resumida de forma concisa (e talvez injusta) pela afirmação de que sentenças da forma " $\times$ não existe" não são simplesmente o que aparentam. Sua genuína forma lógica está escondida pela gramática diária da superfície da linguagem. Essas sentenças aparentam ser sujeito-predicado, no qual se refere a alguma coisa de modo a negar que essa coisa tenha uma propriedade específica, ou afirmar que possui uma propriedade negativa, i.e., não existência. Essa inferência deve ser analisada como algo diferente. Portanto, temos aqui duas importantes compreensões ontológicas: Parmênides e Górgias. Podemos também elucidar uma terceira e intermediária compreensão. Assim, sobre objetos e existência:

1. Tudo existe (Parmênides);

- Uma visão intermediária: A ideia de que algumas coisas existem e outras não (Graham Priest/Meinong). ${ }^{51}$

\footnotetext{
48 (ibid).

49 Exemplo: O nada só pode ser indicado enquanto nada porque não é tudo. A unicidade do objeto se constituí dialeticamente.

50 A posição de Platão não nos interessa. Se o não ser é tudo aquilo que se difere do Ser por ser um Ser-outro, (o) nada passa a ser um algo-outro idêntico a si mesmo, condição que enaltece o princípio de identidade (formal). E nesse sentido, (o) nada não deve ser tomado como igual a si mesmo (Ser) dado que (o) nada não é e não vem (tornar-se) a Ser. (O) nada, nada é.

51 Essa posição será melhor desenvolvida no próximo capítulo.
} 


\section{Nada existe (Górgias).}

Nos parece implausível adotar somente uma destas concepções enumeradas. Enquanto (1) impõe filosoficamente o paradoxo do não ser, (2) interrompe qualquer proceder epistemológico, incapacitando até mesmo uma dúvida. Assim sendo, observaremos que uma terceira opção, concebida como aquela que se situa entre (1) e (2) pode ser engendrada. A concepção de que algumas coisas existem e outras não, está em Meinong ${ }^{52}$ e Priest (Towards Non-Being).

Então, seria possível uma (não) ontologia pautada numa semântica que suporte o não ser? Parece evidente defender que um objeto não existente é simplesmente algo que não existe e, consequentemente, não pode ser colocado em questão. Todavia, pensamos e nos referimos a tais objetos, ainda que não existam. Continuamos a fazer declarações sobre o que "não é" e muitas delas aparentam ter um significado e sentido.

Caso aceitemos que tais sentenças não possuem sentido, ou seja, não podem ser atribuídas como parte de um conjunto de particularidades que implicam a compreensão e afirmação de uma realidade, essas sentenças não podem ser verdadeiras. Em caso de falsidade, a negação é verdadeira e, consequentemente, existe algo que não existe. Sentenças dessa forma parecem nos deixar com apenas duas opções: tais sentenças não possuem sentido ou são falsas por ferirem nossos critérios de realidade. Dito isto, aparentemente a tese de Parmênides, de que tudo existe, se fortifica. Prima facie, nenhum existencial negativo pode ser verdadeiro. É justamente esse critério de realidade que devemos questionar no intuito de estabelecer uma semântica que suporte o não ser. Como falar e pensar sobre o que não existe e se coloca como uma vigorosa contradição?

Convém estabelecer um meio de acesso ao nada, pois, a semântica disponível não o suporta. O princípio de identidade ${ }^{53}$ (PI; "pensar é o mesmo que ser") deve ser destruído. Com isso, podemos empreender esforços na concepção de que é possível pensar e proferir coisas que não existem, atingindo-as.

\footnotetext{
52 MEINONG, A. The theory of objects. In: Realism and the Background of Phenomenology. [S.1.]: The Free Press, 1960. cap. 4, p. 76-117.

53 Até então, todo princípio de identidade a que me refiro pós capítulo I concerne apenas ao "PI" parmenídico, ou seja, este apenas esclarece que "pensar é o mesmo que ser". Reafirmo que, este princípio, até aqui, não deve ser confundido com o princípio de identidade formal no qual temos algo com a forma $\forall \mathrm{x}(\mathrm{x}=\mathrm{x})$.
} 


\section{Em direção ao não ser}

\section{Universos discursivos.}

Primeiramente, a argumentação que se segue legitima e explicita o que se passa quando falamos de objetos fictícios (e impossíveis) e, consequentemente, não existentes. Enunciar algo sobre estes objetos, ainda que metaforicamente, acaba por elucidar o que chamarei de estratégia do "universo discursivo", culminando na estratégia modal de Graham Priest.

Esta concepção sugere que o domínio em que temos e desenvolvemos um certo linguajar e discurso se coloca como um "universo discursivo" e dentro deste universo, uma afirmação pode ser verdadeira ou falsa. ${ }^{1}$ Com isso, podemos repensar e estruturar um sistema discursivo, tornando-o semelhante ou superior ao sistema ontológico proposto por Meinong.

O nosso "universo discursivo" inicial é o mundo "real", localidade que se pressupõe atual e indexical. Logo, numa conversa "normal", a declaração - "Gregor Samsa é um adulto humano que acordou e se viu transformado numa barata" - é uma afirmação falsa, tal como “o planeta (Vulcano) esta escondido entre Mercúrio e o Sol“. Afinal, não é o caso que há um Gregor Samsa e um planeta tal como Vulcano. Ao negarmos a existência de tais coisas (objetos) como possibilidade (causa segundo certas condições) para "Ser" e predicarem algo, o consequente não pode se realizar, ou seja, ser uma barata e ser um planeta entre Mercúrio e o Sol. Tais coisas não existem. Todavia, devemos considerar que quando estabelecemos uma conversa sobre o mundo de Gregor Samsa ou o planeta (Vulcano), acessamos um universo discursivo diferente.

Quando o universo discursivo é o mundo de Gregor Samsa, nossa inferência logo acima se coloca como uma declaração verdadeira, apesar de ser falsa no universo ${ }^{2}$ discursivo do mundo "real". Ontologicamente, não podemos considerar uma realidade em vista de outra, ainda mais se esta for inconcebível. Assim, conscientemente ou não, usamos diferentes universos de discursos, a toda hora, ou seja, não só quando enunciamos sobre universos fictícios, mas também quando falamos, por exemplo, sobre (o) nada. Igualmente, podemos inferir que mundos contém outros mundos, ilustrando universos e galáxias. Por esta mescla, uma enorme confusão adentra nosso mundo atual. Falamos sobre o que não existe considerando um procedimento pautado na existência, assim como consideramos tais objetos (extramundanos e não atuais) como parte do nosso mundo e universo.

Uma maneira de resolver o problema sobre a existência e a veracidade acerca de objetos imaginários é dizer — no caso de Gregor Samsa — que Franz Kafka criou um universo discursivo que é o mundo de Gregor. Sendo que este universo partilha algumas coisas em comum com o nosso, mas também tem diferenças. Assim, no mundo dito real (nosso atual), é falso inferir que Gregor Samsa é uma barata justamente pelo fato de que não há um Gregor Samsa como na história (universo) em que conhecemos. Mas no universo discursivo que é o mundo

1 Como na semântica para a lógica de $1^{\circ}$ ordem.

2 (ibid.) 
de Gregor Samsa, é verdade, porque tanto o Gregor quanto humanos que acordam e se veem uma barata, podem existir. ${ }^{3}$ Portanto, quando falamos de ficção e objetos impossíveis, estamos a usar um universo discursivo particular e os nossos interlocutores sabem ou fingem saber isso, mesmo quando não é dito explicitamente. Isso nos permite dizer coisas que acabam por ser verdadeiras, apesar delas não serem verdade (no mundo "real"/atual). Todavia, a grande questão ainda é, nos relacionamos com tais objetos: Afirmamos suas existências sendo que, ao mesmo tempo, as negamos. Indicar mundos segundo estruturas discrepantes entre si não soluciona nosso problema. Por esta circunstância, as coisas se tornam um pouco mais difíceis e confusas quando o universo discursivo de um mundo fictício ou impossível pode ser o nosso mundo atual. Uma série televisiva, uma história, uma representação (imaginação) que se passa no nosso mundo e obedece a nossa estruturação, todavia, seus objetos (personagens, circunstâncias) não existem sob o nosso espaço-tempo. ${ }^{4}$ Como realizar uma distinção ou atribuir categorias ontológicas para esses dois objetos distintos, mas que, aparentemente, assumem uma mesma posição num dado universo (discursivo)?

Por essa concepção, lidamos cotidianamente com a distinção entre universos discursivos, mundos possíveis e impossíveis, ${ }^{5}$ mas não os compreendemos enquanto estruturações ontológicas. Aparentemente sabemos distinguir o que é cânone e o que não é. Podemos discutir de modo vigoroso e informadamente sobre o que pode acontecer dentro de um discurso e um mundo possível - por exemplo, quem ganharia uma luta entre o Batman e Rocky Balboa? Mas caso tivéssemos uma luta entre Muhammad Ali e Rocky Balboa, quem venceria?

Certamente alguns defenderiam que isso seria impossível e absurdo, outros falariam que Muhhamad Ali ganharia simplesmente porque existe e Rocky Balboa não, enaltecendo um estado ontológico. Situação que estaria apenas priorizando a existência de um em função da não existência de outro, que seria também um erro. O que realmente indica a veracidade da questão? Não temos critérios exatos para inferir o que é real ou não.

Deste modo, compreender que um termo se refere a algo e esse algo necessariamente existe por ser possível ao pensar, não elucida um critério exato de existência e realidade. Foi deste modo que, numa espécie de defesa do Meinongianismo, Russell ${ }^{6}$ compreende níveis de existência mediante a compreensão de que existir é uma prerrogativa para as coisas que são, em

3 Isso remete a ideia de verdade em uma estrutura (Tarski). Para mais informações: Tarski, Alfred. A concepção semântica da verdade. São Paulo. Unesp, 2002.

4 Considere uma série televisiva em que há um personagem (objeto) que é o presidente dos EUA e não é o último presidente eleito no nosso mundo atual. Ambos vivem na Casa Branca e têm os mesmos poderes executivos, sendo que ao contrário do universo discursivo a que Gregor Samsa pertence, o universo dessa trama obedece todas as regras lógicas, físicas e estruturais do nosso mundo. Porque um seria mais real que o outro? Considerar somente a carga ontológica dos objetos não é suficiente. Coisas podem Ser e não existir enquanto existência.

5 Ao lidar com um objeto como (o) nada, veremos que se trata de um objeto impossível por se colocar em um mundo não normal, i.e., que foge completamente a toda e qualquer estruturação possível.

6 Russell, o filósofo em questão, não possui nenhuma simpatia com o pensamento de Meinong. Sua abordagem acerca de objetos não existentes se orienta, além de tudo, para um ceticismo semântico. Em última instância, Russell não aceita os critérios e estruturações ontológicas de Meinong e realiza sua própria concepção sobre o que não há. Meinong reivindica que os objetos em questão não tem qualquer forma de Ser, diferente de Russell. 
algum sentido, todavia, ao passo que existir é ter uma relação com a existência, tal relação não é algo que a existência em si mesma possui, i.e., o existir não se manifesta somente enquanto existência (em sentido ontologicamente restrito, causal e empírico). Questões exploradas na obra Principles of Mathematics: ${ }^{7}$

Qualquer que seja um objeto do pensamento, ou pode ocorrer em uma proposição verdadeira, ou pode ser considerado como algo, eu chamo de (termo)... Todo termo possui um Ser, ou seja, é em algum sentido. Um homem, um momento, um número, uma classe, uma relação, uma quimera ou qualquer outra coisa que possa ser mencionada certamente será um termo; e negar que tal coisa é um termo deve ser sempre falso. ${ }^{8}$

Mais adiante:

... mencionar qualquer coisa é mostrar que tal coisa é. A existência, pelo contrário, é a prerrogativa apenas entre alguns seres. Existir é ter uma relação específica com a existência - uma relação, a propósito, que a própria existência não possui. ${ }^{9}$

Assim, quando pensamos em realidades fictícias ou objetos não existentes, em que diferentes universos de discurso se chocam, ou pior, quando relacionamos e consideramos como factos objetos existentes e não existentes no nosso mundo atual, estamos a entrar em considerações ontológicas bem sérias. Pela junção e incompreensão de universos discursivos (mundos possíveis e impossíveis), ficcionais ou não, existentes ou não, podemos apontar a nossa relação com a ideia do "nada", que pode, como aponta Heidegger, se manifestar através da angústia ou, pela abordagem que adoto, dada a nossa incapacidade de se estabelecer uma caracterização pertinente. Sentimento que pode ser concebido como a redução de um espaçotempo, o padecer do fascínio do possível à ideação de uma ausência e destruição total (nada absoluto), este que se mostra tão bruto que abarrota, ao mesmo tempo, o existir. Nossa relação com (o) nada indica o ápice da incapacidade empírica em abordar diferentes universos de discurso que se chocam.

Por estas e outras considerações, se é o caso que temos na nossa mente um número incrível de proposições específicas para diferentes universos e tentamos descobrir o que seria verdade se esses fossem combinados, seria possível inferir que há um Ser e há também (um) nada (e um não ser)? Ora, é sabido que nossa capacidade de perceber e lidar com realidades fictícias acabam também implicando a possibilidade de lidar com realidades hipotéticas, mas nem sempre

7 RUSSELL, B. Principles of Mathematics. Cambridge: Merchant Books, 1903.

8 Tradução minha: Whatever may be an object of thought, or can occur in a true proposition, or can be counted as one, I call a term... Every term has being, i.e. is in some sense. A man, a moment, a number, a class, a relation, a chimera, or anything else that can be mentioned is sure to be a term; and to deny that such a thing is a term must always be false. (Russell, 1903, p 43).

9 Tradução minha: ... to mention anything is to show that it is. Existence, on the contrary, is the prerogative of some only amongst beings. To exist is to have a specific relantionship to existence - a relation, by the way, which existence itself does not have. (Ibid.) 
compreensíveis em sua totalidade. A ciência no intuito de compreender o mundo lida constantemente com estruturações capazes de descrever o real pautado em processos indutivos e categorias ontológicas inferiores, i.e., podendo ser também inexistentes. O mesmo se aplica com realidades possíveis à (objetos) não existentes que culminam em realidades distintas (impossíveis). Portanto, tratar coisas inexistentes como irreais parece ser um problema. Reivindicações dessa ordem não parecem ser sem sentido, afinal, conseguir criar e conceituar um universo abarca muito mais do que poderíamos conceber como possível no nosso mundo atual. Mundo este que parece limitado a uma semântica que estabelece um vício metafísico e epistemológico (efetivado no agir). Por essas e outras condições, o existir se defronta com (o) nada, elucidando também um problema de fundamentação da tão valorada episteme.

O que entendo por universo discursivo e uma semântica para o não ser acaba por encontrar amparo na semântica de Graham Priest. Aqui, a opção de que algumas coisas existem e outras não parece exequível. Possibilidade que se dá como recurso às implicações teóricas propostas por Parmênides e Górgias. Temos aqui uma terceira (3) opção.

Deste modo, considerando que o paradoxo do não ser se perpetuou na história do pensar, chegando até a filosofia analítica contemporânea, um viés seria compreender o que se atribui à linguagem quando a existência de objetos não existentes vem à tona. Consolidar termos como "objeto", "existência" e "pensar sobre" parece crucial para o desenvolvimento de uma semântica que suporte o inexistente. Podemos então reintroduzir sinteticamente uma percepção contemporânea sobre objetos não existentes. Tal compreensão encontra-se na obra Existence as a real property: The Ontology of Meinongianism, de Francesco Berto (p.06).

(P1) Negar a existência de alguma coisa é se referir a essa coisa.

(P2) Mas se alguém se refere a essa coisa então essa coisa tem que existir.

Portanto,

(C) Para se negar a existência de alguma coisa, então essa coisa tem que existir.

Dando procedimento, Berto argumenta que:

"Da conclusão (C), facilmente se segue que a premissa "tudo existe“ é inques-
tionável. Todas as tentativas de negar os existenciais negativos nos parecem
então falsas ou sem sentido. A lógica necessária para que das premissas (P1) e
(P2) tenhamos (C) é mínima: precisa-se apenas da transitividade do condicio-
nal. Se nos permitimos uma contraposição mínima, (P2) pode ser novamente
apresentada sob uma forma negativa, para que pareça mais produtiva" (BERTO,
F. Existence as a real property: The Ontology of Meinongianism. 2012. p.06).

A essa formulação, Francesco Berto chama "Princípio de Parmênides": (PP) Não é possível se referir a alguma coisa que não exista. Mas seria realmente não possível ${ }^{10}$ Esclareça-

10 O que é, é. O que não é, ainda é algo. O que é impossível, é possível. Ao abordar mundos impossíveis veremos que caso realmente fossem impossíveis, sequer assumiriam a restrição de ser o que são, enaltecendo sua impossibilidade. 
mos, portanto, os termos acima para dissecar o problema e um diagnóstico, com isso podemos introduzir uma semântica.

1) Quais seriam as razões para pensarmos que existem objetos não existentes?

- Existência (predicado/propriedade)

Conforme a significação corrente, uma existência pode ser designada como o fato de existir, realidade, ente, ser, modo de ser atual, concreto. Aspectos que, em última instância, são ilustrados pela concomitância da inferência de que ela seria o modo ou a qualidade de tudo que é "real" e existe. A base de todas as coisas, o modo de ser do próprio existente e a realidade daquilo que aparece naquilo que tem de absurdo e irredutível. Todavia, observamos que compreender os termos "existência", "Ser" e "existir" (ação) como sinônimos e consequentemente como implicação do real parece nos trazer problemas consideráveis.

Todas essas designações acima (P1 a P3) parecem concordar com a ideia de que o que é real é o que existe, mesmo que não tenhamos elucidado (acima) com precisão o que é o real em si. Nesse sentido, indagar o que é a existência, em última instância, tem como intento descobrir a constituição basilar da existência, sua natureza. Assim poderíamos inquirir também os aspectos mais gerais do real. Para tanto, adotaremos um procedimento lógico-linguistico.

Dada uma sentença existencial afirmativa e verdadeira, tal como "Franz Kafka existe", temos gramaticalmente a forma sujeito predicado. Sua forma lógica é como parece: Fa, onde a é F. ${ }^{11}$ Nesse sentido, "Franz Kafka" se refere ao escritor austro-húngaro, autor de $A$ metamorfose, Carta ao Pai, O processo, etc. O termo "existe" se refere a uma propriedade. Franz Kafka tem a propriedade da existência. Consequentemente, o termo tomado enquanto propriedade indica que algo pode possuir ou não a capacidade de existir, já que a existência pelo "existe" pode ser elucidada como uma propriedade de objetos comuns, como peso, altura, calvície, etc. ${ }^{12}$ Ora, no que se refere a indivíduos, seria realmente a existência somente uma propriedade? E caso não aceitemos esta inferência, haveriam indivíduos sem esta propriedade? Tais coisas seriam objetos não existentes, afinal, poderiam assumir outras propriedades, mas não a da existência.

De alguma forma, propriedades contrastam com indivíduos, isto significa que um não pode ser tomado como intrínseco ao outro. Por esta perspectiva, a existência não se coloca como necessária, mas contingente. Caso fosse necessária, seria em todos os mundos possíveis (universos discursivos). Tudo que é, assim como defende Parmênides, necessariamente deveria existir.

Essa distinção, insiste Garrett, pode ser explicitada através da relação de instanciação - exemplo: Meu animal de estimação instancia a propriedade de estar com fome, pois,

11 De outro modo: a: Franz Kafka / F: x existe.

12 Como aponta Garrett em: GARRETT, B. Metafísica: conceitos-chave em filosofia. São Paulo: Artmed, 2008. 
sendo um modo de ser e sendo um indivíduo, não é ele mesmo instanciado por qualquer coisa. Enquanto as propriedades também instanciam - a propriedade de ser vermelho, por exemplo, tem a propriedade de ser uma cor; somente propriedades são instanciadas, indivíduos apenas instanciam.

Como conclusão, caso a existência seja instanciada, i.e., tomada como uma propriedade, convém esclarecer se é o caso que esta seja instanciada por indivíduos como Franz Kafka, minha cadeira, (o) nada, ou minha prateleira de livros. ${ }^{13}$ Os indivíduos, além de assumirem propriedades comuns como o fato de "ser humano", sendo confortável para se sentar e precisar de mais água, instanciam uma propriedade pelo termo "existe"?

- Existência (quantificador).

Uma segunda concepção seria compreender que o termo "existe" não realiza a função de predicado (propriedade), mas de um quantificador: ${ }^{14}$ Trata-se de um indicador, uma propriedade que se aplica a todos os elementos de um todo ou somente alguns entre eles. Em vista disso, "Franz Kafka existe" não é Fa, ou melhor, não pode ser elucidada como a é F, pois, nesse caso, aplica-se $\exists x(x=$ Franz Kafka). Em outras palavras, existe um " $x$ " tal que " $x$ " é idêntico a Franz Kafka.

Concepção que infere que a existência não é uma propriedade de objetos, mas de conceitos, ${ }^{15}$ aspecto que como vimos no primeiro capítulo parece legitimar o pensamento de Parmênides. O nome próprio "F.Kafka" tem a propriedade de ser instanciado.

Entretanto, segundo Graham Priest, ${ }^{16}$ os quantificadores existenciais na lógica clássica são ontologicamente carregados (pesados), isto é: $\exists$ xPx: afirma que o que existe $\mathbf{E}$ algo (e vice versa), delimitando exageradamente um objeto e suas propriedades. Todavia, ainda que um objeto seja idêntico a si mesmo, o que nos parece trivial, não necessariamente o faz existente. Retornamos à noção de que "todos os entes são, mas nem todos necessariamente existem.

Uma saída, segundo Priest, seria remodelar a formulação dos quantificadores de modo que seu alcance seja maior. Por esse objetivo, Priest "desentologiza" os quantificadores (existencial e universal), retirando a carga ontológica de ambos e tornando-os mais abrangentes. Com isso, podemos falar sobre a existência de objetos não existentes pela concepção quantificacional. Visando, sempre que possível, (o) nada.

13 Toda a argumentação e exemplos foram concebidos a partir da obra: GARRETT, B. Metafísica: conceitos-chave em filosofia. p.33-47, São Paulo: Artmed, 2008.

14 Um operador. Quantificador existencial: $\exists \mathrm{x}$ : $\exists \mathrm{xPx}$ - Existe um X que satisfaz as condições dadas pela condição P. Este primeiro é comumente relacionado ao quantificador universal: $\forall \mathrm{x}$ : $\forall \mathrm{xPx}$ - Todo X tem a propriedade $\mathrm{P}$ (O quantificador $\forall$ indica "para todo").

15 E predicados que, por sua vez, também podem ser instanciados.

16 PRIEST, G. Towards Non-Being. The Logic and Metaphysics of Intentionality. Oxford U.P Un; Oxford, p.13-15, 2016. A partir daqui estou me referindo às implicações teóricas contidas na obra Towards Non-Being. 
Então, quais seriam as propriedades que os objetos inexistentes teriam e como se relacionariam com o mundo "atual"? Além de propriedades lógicas, como propriedades autoidênticas e intencionais são pensadas por Priest? Se o quantificador universal utilizado por Priest assume no "desentologizar" o papel de elucidar a existência enquanto predicado (propriedade), a partir da quantificação, não temos mais [existe um $x$ que é], mas somente que [ $x$ existe]. O mesmo se coloca para seu quantificador universal: $\forall x(E x \rightarrow P x) .{ }^{17}$ Em suma, trata-se da afirmação de que para todo objeto $X$, existe um $X$ se e somente $X$ tem a propriedade (P) - (da existência). ${ }^{18}$

Temos então uma nova compreensão para os quantificadores, sendo que Priest aumenta o alcance do quantificador existencial e realiza uma mudança no quantificador universal apenas para acompanhar sua tradução. ${ }^{19}$ Uma compreensão não ortodoxa para quantificadores $(\exists)$ e $(\forall)$, ou seja, o quantificador particular desentologizado é concebido como um indicador não carregado existencialmente. Assim, Priest passa a conceber os quantificadores como: ${ }^{20}$

- $\forall \mathrm{x} \rightleftharpoons \mho x(E x \rightarrow P x)$

- $\exists \mathrm{x} \rightleftharpoons G x(E x \wedge P x)$.

Tudo isso acaba por elucidar o que Priest chama de "princípio de caracterização" (PC). O Ser (sein) de um objeto se dá independente de suas propriedades (sosein): ${ }^{21}$

\begin{abstract}
"Meinong distinguiu o Sein de um objeto de seu Sosein. O Sein de um objeto é seu status existencial — que pode ser nenhum. O Sosein de um objeto compreende as propriedades que possui. E Meinong insistiu que o Sosein de um objeto é independente do seu Sein. Ou seja, o status existencial de um objeto e as propriedades que ele possui são questões bem distintas“ (PRIEST, G. Towards Non-Being. p.82, 2016). ${ }^{22}$
\end{abstract}

Em particular, objetos podem ser caracterizados de muitas formas e ter ou não as propriedades que eles têm não implicam a necessidade de uma existência. Objetos não existentes

17 Sendo que "Ex" não deve ser compreendido como um quantificador, mas o predicado.

18 PRIEST, G. Towards Non-Being. The Logic and Metaphysics of Intentionality. Oxford U.P Un; Oxford, p.13-14, 2016.

19 Justificação em: PRIEST, G. Towards Non-Being. The Logic and Metaphysics of Intentionality. Oxford U.P Un; Oxford, p.13-15, 2016.

20 Priest Quantifiers - Para mais informações: PRIEST, G. Towards Non-Being. The Logic and Metaphysics of Intentionality. Oxford U.P Un; Oxford, p.13-14, 2016. Tentei manter os quantificadores semelhantes ao do livro, sem sucesso. O motivo foi a incapacidade em lidar com códigos de programação do arquivo utilizado para a escrita do trabalho. Assim sendo, realizei uma mudança nos símbolos. De qualquer modo, compreendo os termos abaixo em concomitância ao que consta no livro e nas páginas referidas.

21 PRIEST, G. Towards Non-Being. The Logic and Metaphysics of Intentionality. Oxford U.P Un; Oxford, 2016.

22 Tradução minha: "Meinong distinguished between the Sein of an object and its Sosein. The Sein of an object is its existential status - which may be none. The sosein of an object comprises the properties that it has. And Meinong insisted that an object's Sosein is independent of its sein. That is, the existential status of an object and what properties it has are quite separete issues" - PRIEST, G. Towards Non-Being. The Logic and Metaphysics of Intentionality. Oxford U.P Un; Oxford, p.82, 2016. 
podem assumir propriedades, i.e, dado um nível de existência (um mundo que o suporte). Essa condição não infere um existir.

Por este prisma, finalizo a argumentação sobre como Parmênides não exemplifica muito bem o que significa "existir". Sua condição se dá justamente pela estruturação do Ser, em oposição ao não ser. E entre a concepção de que tudo existe e que nada existe, o paradoxo do não ser ou o problema dos existenciais negativos elucida concomitantemente um problema de referência. Se não é possível se referir a alguma coisa que não existe, o que a expressão "se referir a" significa aqui? Trata-se de um termo, como aponta Berto, ${ }^{23}$ "intencionalmente" não específico. Ao considerarmos o quantificador existencial como aquele capaz de abarcar um objeto de modo não carregado ontologicamente, podemos também indicar a possibilidade da existência de objetos não existentes, aclarando nosso tracejar em direção ao nada.

\subsection{Intencionalidade ${ }^{24}$ e objetos não existentes}

Ao situarmos o paradoxo do não ser em termos linguísticos, podemos inferir que temos palavras e frases nominais. O termo "refere-se a" elucida, em última instância, a ideia de que objetos denotam. Assim, a ideia de que "Gregor Samsa", "Sísifo" ou (o) nada 25 se referem a algo, significa que estes são somente se é o caso que há essas coisas, ou seja, existem. Mas afirmar que algo existe é crer na existência de tal objeto. A isso se deve o termo "intencional", ou de outro modo, "intencionalidade". Característica que pode ser apontada como fundamental à cognição.

Em suma, a intencionalidade pode ser compreendida como a característica de um estado mental que se estrutura pelo direcionamento a um objeto de qualquer forma. Demarcado linguisticamente por verbos tal como "sabe", "crê", "acredita", "teme", "adora", e assim por diante. Deste modo, se nos referimos a algo é porque pensamos nesse algo (objeto), e se podemos pensá-los, ao menos alguns deles, de alguma forma são. Mas como proceder mediante objetos não existentes? Estes são e assumem um Ser?

Dada sua Teoria dos objetos, ${ }^{26}$ o filósofo austríaco Alexius Meinong se preocupou com o problema dos estados intencionais que não se direcionavam a qualquer coisa existente, procurando constatar o estatuto ontológico desses objetos. O ponto inicial deste problema, também chamado de "princípio da intencionalidade" afirma que o fenômeno mental se caracteriza

23 BERTO, F. Existence as a real property: The Ontology of Meinongianism. EUA: Springer, p.06, 2012.

24 Não confundir "inten(c)ional" com "inten(s)ional”O primeiro se refere ao conceito filosófico atribuído a Franz Bentrano e indica que a consciência é sempre consciência de alguma coisa, i.e, a intencionalidade é tomada como o estatuto da consciência. O segundo termo indica o modo de aplicação de um termo ou expressão a uma extensão, sendo o significado ou termo de um predicado.

25 Enquanto "Gregor Samsa" e "Sísifo" denotam personagens (fictícios) inseridos em um mundo ontologicamente discrepante ao nosso (empiria, leis lógicas e temporais, etc), esse mundo ainda é dotado de propriedades. A dificuldade em pensar (no/o) nada se dá justamente pela impossibilidade de denotar e apontar suas propriedades específicas.

26 MEINONG, A. The theory of objects. In: Realism and the Background of Phenomenology. [S.1.]: The Free Press, 1960. cap. 4, p. 76-117. 
por um direcionamento intencional para um objeto. Deste modo, amar é amar alguma coisa, imaginar é sempre imaginar alguma coisa, acreditar - acreditar em alguma coisa, assim por diante. Em outras palavras, todo ato intencional é "sobre" alguma coisa.

O problema é que às vezes as pessoas imaginam, desejam ou temem coisas que não existem. Algumas pessoas temem (o) nada ou dizem carregá-lo, ainda que este não se manifeste empiricamente e seu conceito seja muito mau compreendido. Muitas pessoas anseiam pela paz no mundo, mesmo que o conceito de paz pareça ser mal formado e sua referência pouco esclarecida.

Casos como estes parecem ser contraexemplos claros para o princípio da intencionalidade. O direcionamento intencional a um objeto não possível parece inviabilizar o próprio princípio de intencionalidade. Todavia, muitos filósofos acharam este princípio muito atraente para ser ignorado. Enquanto alguns chegaram à conclusão de que a intencionalidade não é uma relação real e, portanto, não exige a existência de um objeto, Meinong ofereceu outra solução: existe, de fato, um objeto para todo estado mental, se não um objeto existente, pelo menos inexistente da perspectiva empírica.

Podemos considerar então o problema da intencionalidade como uma das mais importantes motivações para se pensar a favor da existência de objetos não existentes. Por esta perspectiva, Graham Priest considera a intencionalidade como uma ferramenta extremamente considerável para se pensar e desenvolver uma semântica sobre o que não existe. Afinal, se é através da nossa estrutura epistêmica que no relacionamos com o que não é, cabe compreender como se dá essa relação e, por conseguinte, como a mesma pode ser descrita.

A defesa da questão consiste basicamente no fato de que a discussão contemporânea de como tratar verbos intencionais com objetos não proposicionais é quase inexistente e o status de objetos (possíveis e impossíveis) é um debate em andamento. Por esse e outros interesses, Priest realiza uma importante análise de contextos intencionais desenvolvendo uma semântica para verbos intencionais, os princípios lógicos relativos às noções intencionais que geram a semântica e acima de tudo as interpretações metafísicas da semântica. Sua estratégia se baseia no que ele intitula [noneísmo], Berto prefere chamar Meinongianismo modal. ${ }^{27}$

O termo noneísmo, cunhado por Richard Routley, é assumido por Priest nas suas mais essenciais ferramentas. Ao proceder deste modo, Priest assume quantificadores não carregados e mundos meramente possíveis e até impossíveis, sendo que todos os mundos (possíveis, assim como os impossíveis) compartilham o mesmo domínio no discurso. Mas nem todos os objetos do domínio existem em todos os mundos. Portanto, podemos inferir que, um objeto como "Pegasus" não existe no mundo atual, mas existe em uma variedade de mundos meramente possíveis (nomeadamente naqueles que são representados pela mitologia grega). Por essa estratégia, objetos não existentes literalmente possuem as propriedades pelas quais são "caracterizados", sendo que possuem essas propriedades de modo que elas só são possíveis no mundo em que

27 Ambas elucidam um mesmo desenvolvimento e procedimento. Como este trabalho foi realizado utilizando a obra de Priest, utilizarei a palavra "noneísmo". 
estes objetos habitam, não sendo possível no nosso mundo (atual).

Então, a estratégia modal (mundos e universos) fornece uma solução para o paradoxo do não ser: Um círculo-quadrado existe somente em um mundo "impossível". Em mundos que se colocam impossíveis, PNC não se sustenta. Ser círculo e, ao mesmo tempo, ser quadrado, não infringe as leis da lógica que sustentam a existência de um objeto como esse no mundo que existem. Em mundos impossíveis as leis lógicas podem simplesmente não existir.

No mundo atual, entretanto, um círculo-quadrado não é círculo, muito menos quadrado, uma vez que a redondeza e a quadratura são "propriedades que possuem existência", ou seja, se manifestam no espaço-tempo. Assim, afirmar que " $b$ é círculo/quadrado" implica " $b$ existe“. Portanto, mesmo que no nosso mundo (atual, e em todos os outros mundos possíveis) a lei da contradição se mantenha, um quadrado redondo não infringe esta lei (em um mundo imposível), uma vez que nesses mundos o quadrado-redondo não é quadrado nem redondo.

À luz dessa teoria parece fácil explanar porque ninguém pode ver um círculoquadrado, e porque um círculo-quadrado obviamente não se localiza no espaço. Desde que um círculo-quadrado não é nem quadrado nem redondo no mundo atual, não há razões para assumir que este objeto ocupe um espaço, ou seja, se manifeste enquanto acessível aos sentidos. O mesmo se aplica, caso utilizemos (o) nada como exemplo. Por ser contraditório, o nada não é, i.e., não é Ser e não ser (enquanto complemento ao que é). De outro modo, (o) nada, nada é, e por nada ser, não pode também assumir uma totalidade negativa. Sua totalidade só se faz possível na medida em que se coloca como uma não totalidade, não encerrada em si.

\subsection{O acesso "ao" nada (semântica e operadores)}

\section{Uma semântica para uma linguagem intencional: Operadores e predicados.}

Por este subitem apresento e desenvolvo uma semântica que suporte o não ser. Deste modo, a argumentação que se segue é toda baseada na obra Towards Non-Being de Graham Priest, explorando suas implicações, aplicações e dificuldades. A estruturação que se segue está sob três pilares:

- (1) Uma semântica modal, incluindo mundos não normais, também conhecidos como mundos impossíveis;

- (2) O estabelecimento de um princípio sem restrições sobre as propriedades que podem caracterizar objetos;

- (3) Uma distinção intuitiva entre propriedades que implicam existência e propriedades que não implicam.

Explicito então, via Priest e a estratégia de mundos, pautada na lógica modal alética, como universos discursivos podem assumir diferentes estruturações e se relacionar com 
objetos possíveis ou não (impossíveis). A lógica modal alética é utilizada como recurso para a compreensão desses universos e mundos. Ela é aquela que se ocupa dos conceitos de necessidade e possibilidade. Nesse sentido, lidar com universos discursivos nos leva a "modos de verdade" (Alética de Alétheia, da palavra grega, significa "verdade"). Com isso, temos que uma proposição, enquanto indicativo de imputação do real, além de ser (contingentemente) verdadeira ou falsa, pode ainda ser necessária (i.e., necessariamente verdadeira) ou impossível (i.e., necessariamente falsa). Esse procedimento consiste, basicamente, na adição à linguagem da lógica clássica os operadores unários $\square$ e $\diamond .{ }^{28}$

Sob este desenvolvimento, Priest realiza uma distinção entre o que ele chama de "operadores" e "predicados". Observemos sua construção para que possamos compreender como a lógica modal se aplica a mundos possíveis e, por fim, mundos impossíveis.

Nos parece claro que ao observar verbos intencionais, tais como "acreditar", "imaginar", "adorar", "temer", estes assumem diferentes formas de complemento e universos. Por vezes o complemento gramatical de um verbo intencional é uma frase (forma) nominal. ${ }^{29}$ Assim, certas sentenças contêm um complemento para um estado cognitivo que não contêm, necessariamente, noções de ação, processo (ou estado) e ocorrência. Deste modo, por ação ${ }^{30}$ ou ocorrência ${ }^{31}$ compreendemos um processo causal ou manifestação empírica, ou seja, uma relação com o que indica uma concretude e consequência. Já um verbo intencional nem sempre cumpre tais funções, não é o caso que se relacione sempre com o que assume uma condição (causal, empírica) no nosso mundo atual. Do mesmo modo, por uma condição de processo ou ocorrência, ou seja, verbos que podem ser apontados por "ser", "estar", "permanecer", indicando a unicidade do objeto referido, parecem esbarrar novamente num problema ontológico, tal como afirmar que $(X)$ deseja ser (y), ou seja, ser outro e ainda sim o mesmo. O padrão de admissibilidade ontológica possui diversas interpretações. Portanto, no que concerne a complementos gramaticais de um verbo intencional, e objetos não existentes, temos seres que estão a se relacionar com objetos mentais que não se manifestam empiricamente e em última instância, não são. Estamos a tratar de verbos não explícitos que indicam um desejo, sendo que é possível, por exemplo, desejar coisas inexistentes, i.g.: ${ }^{32}$

\section{- Ponce de Leon anseia pela pedra filosofal.}

- Os gregos antigos veneravam Zeus.

28 Cujos significados são: $\square \alpha$ : é necessário que “ $\alpha$ ”/necessariamente “ $\alpha$ ”; $\diamond \alpha$ : é possível que “ $\alpha$ ”/ possivelmente " $\alpha$ ".

29 As formas nominais do verbo são o gerúndio, infinitivo e particípio.

30 Compreendido por verbos como: “fazer", “mandar", “estudar", “contruir”, etc. Se alguém estuda, esse alguém estuda algo.

31 Compreendido por verbos como: “acontecer", "suceder”, “ocorrer”, “decorrer”, "passar”. Se é o caso que algo sucede, essa coisa se sucede de algo.

32 Os dois primeiros exemplos foram retirados de: PRIEST, G. Towards Non-Being. The Logic and Metaphysics of Intentionality. Oxford U.P Un; Oxford, p.06, 2016. 
- O filósofo Martin Heidegger acredita no nada.

Os complementos dessas sentenças, entretanto, também podem ser (possivelmente precedidos pela cópula “que"):

- Milan Kundera acredita (que) Gregor Samsa é uma barata.

- Nietzsche sonhou (que) era Deus.

- Karl Marx teme (que) a história não atinja sua finalidade.

As sentenças acima assumem indivíduos que estabelecem uma relação mental com um objeto (existente ou não). O objeto a que o estado mental se direciona em casos como esse pode ser compreendido como uma proposição expressa pela sentença embutida. Em suma, sentenças dessa forma relatam crenças de uma pessoa, normalmente explicitando que o sujeito do relato concordaria com a frase do conteúdo (propriedades) do relato. A frase do conteúdo de um relato é simplesmente a sentença embutida que caracteriza a crença que esta sendo relatada. Isso significa que complementos intencionais desse tipo também podem aparecer em forma de oração infinitiva-acusativa, tal como: - Milan Kundera acredita ser um ótimo escritor.

Por esta exposição, Priest chama verbos intencionais com complementos nominais de predicados e verbos intencionais com complementos relativos à sentença de operadores. Alguns verbos podem ser somente predicados, com isso, predicados intencionais normalmente são binários ou assumem mais relações. Ver exemplos em Priest, Towards Non-Being, p.07 - 08.

Em suma, podemos indicar tal distinção pelo alcance e expansão da lógica modal em relação a lógica proposicional e de predicados, acrescentando operadores que se referem a modos. ${ }^{33}$ Assim sendo, podemos destacar que, se um complemento nominal estabelece o sentido de um verbo (intencional), ao ser pontuado como operador, uma sentença assume condições de possibilidade legitimando a função do verbo intencional. De outro modo:

- Operador $\Longleftrightarrow$ Lógica Modal

É possível que chova $(\mathrm{p}) \rightarrow \diamond \mathrm{p}$

É necessário que chova $(\mathrm{p}) \rightarrow \square \mathrm{p}$

* - "Eu adoro que você goste da mim": Que alguém goste de mim é condição necessária para que eu adore (verbo intencional) que a pessoa goste de mim. Sendo a cópula "que" um meio de ligação do verbo ao complemento nominal. Todavia, é possível que alguém ache e adore que outra pessoa gosta dela, não sendo o caso que a pessoa gos. São modos de verdade referente à sentença.

33 Possibilidade, impossibilidade, probabilidade e necessidade. 
- Predicado $\rightarrow$ Lógica de Predicado

$\mathrm{Vx}: \mathrm{x}$ é possível $\hookrightarrow \mathrm{Vc}$

$\mathrm{Nx}$ : $\mathrm{x}$ é necessário $\hookrightarrow \mathrm{Nc}$

*Considerando a lógica de predicados, uma declaração deve ser verdadeira ou falsa, dependendo do valor de suas variáveis. Portanto, não é possível que algo seja falso e verdadeiro ao mesmo tempo, pois, caso seja falso, será necessariamente falso. Se é o caso que "eu adoro você", não podemos assumir uma relação de modalidade. Alguém adora outra pessoa ou não (verdadeiro ou falso).

Por operadores modais, ao lidarmos com verbos intencionais e objetos não existentes, i.e., estabelendo uma relação com o que não é, podemos compreender o estatuto ontológico do objeto mental em destaque. Enquanto uma lógica de predicados estabelece aquilo que se declara a partir da forma $\mathrm{P}: \mathrm{X} \rightarrow\{$ verdadeiro ou falso $\}$, pela lógica modal podemos indicar a possibilidade de um verbo intencional com um complemento relativo à sentença de modo que sua realidade se faça possível dentro de um domínio do discurso em que uma propriedade é possível, mas não necessária. Com isso, podemos nos relacionar com objetos não existentes que não indicam necessariamente uma condição de verdade, ou seja, não são verdadeiros nem falsos.

\subsubsection{Mundos possíveis}

Quando os filósofos e os lógicos se referem ao "mundo atual” (por vezes tomado como "real"), ao contrário de outros mundos meramente possíveis, o primeiro não significa a Terra, o sistema solar ou os nossos tempos atuais. Mesmo as galáxias mais remotas pertencem ao mundo real neste sentido. Os gregos antigos e homens do futuro também pertencem a ele. Nesse sentido, um (o) mundo é tomado como a maneira mais geral e abrangente em que as coisas são o que são. Isso significa que no mundo atual, Napoleão lutou em waterloo, observo a chuva da minha janela enquanto escrevo essas palavras em meu computador, a Universidade de Brasília possui um Departamento de Filosofia, etc. Todavia, as coisas podem ser diferentes de várias maneiras: um sol rigoroso poderia consumir o dia que estou a observar pela minha janela, Napoleão pode ter desistido ou hesitado em começar uma guerra, estou a escrever essas palavras no papel e não num computador, a Universidade de Brasília não possui um Departamento de Filosofia. Deste modo, chamamos "mundos possíveis" formas alternativas em que uma coisa poderia ser ou assumir.

O que deve ser, portanto, uma semântica para uma linguagem que contêm operadores intencionais e como se relaciona com mundos possíveis? Segundo Priest, nossa semântica deve se basear numa espécie de "semântica de mundos", assumindo e considerando, por meio da modalidade, estruturas possíveis e necessárias, contingentes ou não. Tais termos foram alavancados por Leibniz, segundo a compreensão de que o que é necessário é o que vale em 
todos os mundos possíveis (e o que é o contingente é o que vale em alguns mundos, mas não todos, etc.).

Mediante o exposto, é conhecido que os operadores modais (necessidade e possibilidade) podem ser, então, vistos como uma quantificação de mundos, i.e., nos dando uma caracterização intuitiva sobre ou modos de ser das coisas em questão. Nesses mundos, as leis lógicas são tradicionalmente tomadas como princípios que asseguram e se sustentam em todos os mundos possíveis, ou seja, indicando o que pode acontecer e o que é possível que aconteça. Deste modo, fixada as leis lógicas, nunca teremos a violação de um princípio de identidade formal (" $\alpha$ " não idêntico a " $\alpha$ ”) ou uma contradição será verdadeira. Essas coisas são circunstâncias não possíveis em relação à lógica clássica. Aspecto que como veremos, não se sustentam em antirealidades, ou seja, mundos impossíveis.

Considerando, portanto, a explanação sobre os operadores $\square$ (necessário) e $\diamond$ (possível): Na literatura sobre lógica modal, é amplamente conhecido que: $(M)$ é uma tripla tal que $\langle W, R, v>: W \neq \emptyset$, " $R$ “ é uma relação de acessibilidade $R$ “ $\subseteq W \times W$ e $v$ é uma valoração que atribui sentenças em mundos possíveis uma condição de verdade. Isso funciona do seguinte modo:

- $w \Vdash \mathrm{P}$ ou $w \neg \Vdash P$ (para p. atômica);

- $w \Vdash \neg \varphi$ sse $w \neg \Vdash \varphi$;

- $w \models \varphi \wedge \psi$ sse $w \Vdash \varphi \wedge \Vdash \psi$

Para outros operadores, basta seguir a lógica clássica. Para $\square$ e $\diamond$, temos:

- $w \Vdash \diamond \varphi$ sse $\exists w^{\prime}$ t.q. $w R w^{\prime}, w^{\prime} \Vdash \varphi$,

- $w \Vdash \square \varphi$ sse $\forall w^{\prime}$ t.q. $w R w^{\prime}, w^{\prime} \Vdash \varphi$.

Contudo, fundamentada sob uma lógica modal de $1 .^{\circ}$ ordem (S5), a lógica modal de Priest é discrepante da lógica modal alética. Lidaremos então com uma semântica alterada e pautada na intencionalidade. Assim, considerando um termo " $t$ " e uma fórmula " $A$ ": Sendo $t \psi \mathrm{A}$ uma fórmula, onde " $\psi$ " é um operador intencional, temos que $\mathrm{t} \psi$ ' $s$ que A, (" $\mathrm{t}$ " acredita/crê/teme... A). ${ }^{34}$

Como estamos lidando com uma linguagem que se baseia em operadores modais, convém também adotar $\square$ para necessário e $\diamond$ para possível. Uma interpretação a qual irei me referir pelo símbolo $\gamma$, para a linguagem da estrutura $<C, @, D, \delta>-$ Sendo $C$ um conjunto de mundos, cada um está fechado em si, então nós os chamaremos de mundos fechados; @ é o

34 PRIEST, G. Towards Non-Being. The Logic and Metaphysics of Intentionality. Oxford U.P Un; Oxford, p.09-13, 2016. 
mundo atual; $D$ é um domínio de objetos, e $\delta$ atribui a cada símbolo não-lógico uma denotação. Portanto:

1) Se c é uma constante, $\delta(c) \in \mathrm{D}$.

2) Se f é uma função n-ária, ${ }^{35} \delta$ (f) é uma função n-ária em $D$.

3) Se P é um predicado n-ário, e $w \in C, \delta(P, w)$ é um par, qual podemos escrever como $<\delta+(P, w), \delta-(P, w)>$

4) Se $\psi$ é um verbo intencional, $\delta(\psi)$ é uma função que mapeia cada $d \in D$, para uma relação binária em $C$. Assim, temos $\delta(\psi)(d)$.

Então, um mundo que pertence a um domínio de objetos, dada uma função entre "n" elementos, i.e., uma relação, podemos atribuir que a mesma é uma função "n" (n-ária“) em um certo domínio de objetos. Isso significa que um objeto pode assumir diversas estruturações (possíveis) segundo a função ou operação em que se encontra. Segue-se que se um predicado n-ário vincula-se a " $w$ " que pertence a um mundo possível, podemos atribuir uma denotação " $\delta$ ", em que $\delta$ assume a propriedade " $P$ " em " $w$ “. Esse conjunto de coisas, a partir da estruturação em que se estabelece, pode ser valorado, ou seja, " $\delta+(P, w)$ “ para verdadeiro e $\delta-(P, w)$ para falso. Essa indicação elucida a extensão e a co-extensão de um predicado, ou seja, constituindo aquelas coisas a que o predicado se refere, podemos apontar o objeto em questão como parte de uma classe de objetos a que o mesmo descreve e se aplica. Assim, um objeto não existente se dá pela perspectiva que tal objeto tem de satisfazer certas condições para ser corretamente descrito pelo predicado. Por fim, dado um verbo intencional como um primeiro meio de acesso ao domínio de objetos, podemos inferir um verbo intencional $(\psi)$ e, por conseguinte, denota-lo $\delta \psi$ para que o mesmo seja compreendido enquanto uma função, i.e., uma relação capaz de mapear um discurso referente a um domínio de objetos, estabelecendo uma relação entre uma coisa e outra, ou seja, uma relação binária entre um conjunto de mundos, o mundo atual e um mundo possível.

Em suma, dada uma denotação, ou seja, um vínculo direto de significação que um nome estabelece com um objeto da realidade num conjunto de mundos constantes e pertencentes a um domínio, podemos inferir que " $P$ " é uma função que atribui um valor verdade (V ou $F$ ) às sequências de $\mathrm{n}$ indivíduos de um domínio de discurso, i.e., um valor de verdade $\mathrm{V}$ ou $\mathrm{F}$ em um mundo $(P+$ valorado em " $w$ " / $P$ - valorado em um " $w$ " $)$.

Agora podemos especificar o que é para uma frase, A, ser verdadeira ou falsa, no mundo com respeito a uma avaliação das variáveis livres, " $s$ " (e uma interpretação, $\gamma$, mas isso normalmente será tomado para concedido). Priest estabelece tais relações como $(\mid \vdash+)$ para verdadeiro e $(\mid \vdash$-) para falso. A validade $(\mid \vdash)$ é definida como mecanismo de preservação da verdade em @ para cada interpretação. Portanto, podemos considerar: $w \vdash+$ +"s"A e $w \vdash$-“s” A

35 Relação n-ária: Uma relação n-ária $\mathrm{R}(\mathrm{x} 1, \ldots, \mathrm{xn})$ é uma relação entre $\mathrm{n}$ elementos. Ex: A relação entre um indivíduo, seu sentir, crença e o objeto da sua crença é uma relação quaternária. 
Ao passo que esses operadores intencionais se colocam como válidos apenas em @ , temos que nosso domínio de mundos diz respeito ao Ser, ou seja, uma forma do tipo $w \vdash+$ $\square$ A SSE para todo w' $\in C, w^{\prime} \Vdash+$ A. Exemplificando, temos um domínio de mundos em que A é verdade (necessário) SSE é o caso que o que este mundo contém pertence ao conjunto de mundos. O Ser se dá em mundos fechados, ou seja, caso uma valoração para fórmulas não atômicas: ${ }^{36}$

Se $\vdash \mathrm{A} \rightarrow \vdash \mathrm{t} \psi \mathrm{A} ;{ }^{37}$ Se A então t acredita que $\mathrm{A}, \log \mathrm{t} \psi \mathrm{A}, \mathrm{A} \rightarrow \mathrm{B}$ t $\psi \mathrm{B}$.

Isso significa que: se A se dá em um mundo qualquer a partir da avaliação de variáveis livres, i.e., uma variável que ainda não possui um valor de verdade, podemos inferir A é o objeto em questão e se é o caso que há tal objeto é porque alguém (t) estabelece uma relação intencional com o mesmo. Então, um indivíduo acredita em A que é causa para B, assim sendo, “t” estabelece uma relação intencional com B.

\subsubsection{Mundos impossíveis}

Por outro lado, mundos impossíveis se caracterizam por violar as leis da lógica, são mundos anormais e que não se assemelham ao nosso mundo. ${ }^{38}$ Aqui podemos nos direcionar ao não ser. Por esta compreensão, podemos pensar que, anteriormente nos deparamos com o que existe (empiricamente) e por existir, assume um Ser, assim como outros objetos podem assumir um "Ser" e não assumir uma existência strictu sensu (empírica por exemplo). Contudo, ao lidarmos com mundos impossíveis, nos deparamos com objetos que assumem uma estrutura e se colocam como coisas podem não ser? Meinong, Graham Priest e Francesco Berto acreditam que sim. Muitas vezes falamos sobre impossibilidades, sobre como as coisas não podem ser, em sentido restrito ou relativo. Isso não significa que, no caso de uma descrição definida ou o esforço em denotarmos um objeto, o mesmo se manifesta como aquele que não possui um Ser.

Ora, tomemos como exemplo uma situação mais concreta: um indivíduo esta preso numa fila de banco para pagar um aluguel que, caso não pago acarretará seu despejo; sendo que o horário final de funcionamento da instituição bancária se aproxima, ele não será atendido. Dado o tempo previsto, não há um modo de atrasar todos os relógios de todas as pessoas ali presentes e ser atendido, e mesmo que fosse possível, o mundo continuaria a seguir seu curso mediante a convenção de um tempo pré-estabelecido socialmente. No entanto, intuitivamente, tal condição não é irrestrita ou absolutamente impossível. Se essa pessoa tivesse um instrumento para voltar no tempo, tal como o utilizado na obra "O guia do mochileiro das galáxias", esse indivíduo poderia voltar no tempo e pagar sua conta. Todavia, o mundo da obra "O guia do mochileiro

\footnotetext{
36 Checar a estruturação semântica para uma linguagem intencional: PRIEST, G. Towards Non-Being. The Logic and Metaphysics of Intentionality. Oxford U.P Un; Oxford, p.10-11 2016

37 Tomamos " $\psi$ " como um operador intencional. Assim sendo, se 't $\psi$ A“, logo "t" acredita, teme, adora " A“, ou qualquer outro verbo intencional.

38 Mundos impossíveis são completamente discrepantes dos mundos possíveis.
} 
das galáxias" (GMG) é pautado na possibilidade da criação de um universo completamente discrepante do nosso atual, atingindo diferentes e absurdas estruturações.

Algumas (muitas) pessoas duvidam que tais mundos sejam fisicamente possíveis. Um mundo onde teríamos um objeto completamente contraditório e que escapasse a uma apreensão, aos nossos procedimentos epistêmicos e lógicos. Podemos, no entanto, lidar com esta compreensão segundo a inferência de que a obra em questão (GMG) descreve um mundo com essas características, efetivando-as. Generalizando, não é difícil conceber ou representar para nós mesmos mundos que leis físicas e biológicas não se aplicam. Com isso, leis lógicas também não se realizam. Um mundo em que as torres gêmeas (ambas) em Nova Iorque desabaram em dias e anos diferentes, ${ }^{39}$ ou a manifestação "do" nada em um universo inexistente, ou seja, anterior à criação do universo mesmo. Alguns mundos podem ser considerados fisicamente e biologicamente impossíveis, e tais parâmetros uma vez inseridos numa lógica, parecem inviabilizar a indagação e inquirição de qualquer objeto.

A questão é que esses mundos, apontados como impossíveis em sentidos específicos, não são absolutamente impossíveis. Caso o fossem, nem sequer poderiam assumir uma restrição. É por isso que tais mundos ainda contam como mundos possíveis. ${ }^{40} \mathrm{O}$ mundo que aqui nos interessa não deve ser possível, i.e., entendido em um sentido completamente irrestrito.

Os mundos (im)possíveis (sem restrições) a que nos referimos, isto é, todos os aspectos das coisas parecem ainda indicam um Ser, o que é. Os mundos que nos interessam são mundos (absolutamente impossíveis) que não estão lá, não assumem um Ser (de acordo com Meinong). Não estão em lugar algum. Nesses mundos as leis da lógica, tais como o princípio da identidade, princípio da não-contradição, são assumidos como os mais gerais e neutros em termos de tópicos: eles mantêm todos os mundos possíveis (sem restrições).

Se em mundos (im)possíveis as estruturações lógicas se diferem completamente do nosso mundo atual, $\delta$ trata sentenças do tipo $\mathrm{A} \rightarrow \mathrm{B}$ como sentenças atômicas, i.e., $\delta+(\mathrm{A} \rightarrow$ $\mathrm{B}, w)$ e $\delta$ - $(\mathrm{A} \rightarrow \mathrm{B}, w)$. Sendo “+” aquilo que indica uma sentença verdadeira e "-" aquilo que indica uma falsa. Assim, toda sentença do tipo $\square$ A (A é necessário) é falsa e toda sentença do tipo $\diamond \mathrm{A}$ (é possível) é verdadeira, ou seja, nada é necessário, tudo é possível.

Segue-se, portanto, que objetos que não existem residem em mundos que asseguram procedimentos contrários ao nosso mundo e universo discursivo. Por esta inferência, é possível que haja um campo semântico ontológico capaz de ilustrar/ser um arcabouço teórico que suporte o não ser. Isso significa que uma semântica para este objeto deve conseguir elucidar contradições verdadeiras e não nulas, de modo que o não ser possa ser concebido e isso não o faz ser.

39 Não é possível que a coisa deixe de ser e continue sendo. Assim, não é possível que a torres (sendo as mesmas torres) desabem duas vezes, ou melhor, duas vezes em datas distintas (Ex: 11 de Setembro e 15 de Setembro).

40 São mundos ontologicamente ínferos. Sua carga ontológica parece ser tão insuficiente que os procedimentos da razão não atingem os aspectos mais basilares dos objetos (impossíveis) em questão. Com isso, indicamos que não há um Ser, não há o que ser apreendido. 


\subsubsection{Modalidade e noneísmo}

Por esta intenção, na lógica modal de predicados, domínios variáveis são mais apropriados para uma semântica de mundos do que um domínio constante. Universos discursivos assumem diferentes estruturas em relação a outros, por isso, na lógica modal de predicados, lidar com um domínio constante seria desconsiderar suas particularidades, possibilidades e impossibilidades. Todavia, ainda parecemos considerar tais objetos existentes enquanto parte de um mundo. Essa visão é rejeitada pelo noneísmo. Mundos impossíveis e consequentemente objetos impossíveis não possuem um Ser, afinal, eles não são. Aspecto explicitado por Priest, fazendo uma referência à lógica modal quantificacional:

[... ] parece não haver nenhuma razão para que o domínio de cada mundo não seja exatamente o mesmo, ou seja, o conjunto de objetos - o status existencial de um objeto nesse mundo. Esse status é expresso pela implantação de um predicado de existência. Ou seja, assumimos que é expresso por um predicado unário, $E$, de modo que os objetos existentes em um mundo, " $W$ ", são precisamente aqueles que estão na extensão de $\mathrm{E} \operatorname{em} \mathcal{W}, \delta+(\mathrm{E}, \mathcal{W}) .{ }^{41}$

Segue-se que, destacar o Ser de um objeto segundo a forma quantificacional $\exists \mathrm{xA}(\mathrm{x}) /($ existe algo, $x$, tal que $A(x)$, e supondo que a existência e o ser são a mesma coisa não convém ler a forma lógica como "há algo, $\mathrm{x}$, tal que A (x). A leitura "algo, x, é tal que A (x) é suficiente. Portanto, uma forma lógica como $G x(P x \wedge Q x)^{42}$ se coloca como: algum "x" é tal que "x" é um P e "x" é um Q. De modo mais simples, alguns Ps são Qs. A estratégia noneista consiste em desontologizar os quantificadores. A existência não se assume como sinônimo de Ser.

Deste modo, podemos compreender $\mathrm{Gx}(\mathrm{Ex} \wedge \mathrm{Ax})$ como uma forma elegante de atribuir um estado ontológico a objetos. Caso compreendamos o mesmo como ExPx, convém recordar que na possibilidade um objeto, o mesmo se faz a partir das propriedades que assume. Assim, se é o caso que há um $G x$, existe um objeto $\times$ e esse $\times$ assume a propriedade $\mathrm{A}$, ou de modo ortodoxo, existe um $\times$ e $\times$ é $P$, todavia, não $P$ não é condição necessária para a existência de $\times$, mas apenas uma propriedade que enaltece seu caráter ontológico.

A estratégia noneísta consiste em supor que a existência é um predicado ordinário, ou seja, que se faz presente, mas não necessário. Sendo o caso que podemos indicar um objeto completamente desprovido de existência. Ocorre, portanto, que o noneísmo é uma teoria lógica e metafísica que se coloca como a reivindicação que sustenta que algumas coisas não existem. E que, em última instância, podemos quantificar objetos não existentes utilizando o chamado

41 Tradução minha: "[...] there would seem to be no reason why the domain of each world should not be exactly the same, namely the set of all objects - whatever an object's existential status at that world. This status is expressed by deploying an existence predicate. That is, we assume that there is a one place predicate, E, such that the existent objects at a world, $w$, are precisely those that are in the extension of $\mathrm{E}$ at $\mathcal{W}, \delta+(\mathrm{E}, \mathcal{W})$ “ (PRIEST, Towards Non-Being, p.13).

42 Estou tomando a letra "G" como indicativo de "algum x". Como apontei anteriormente, a mudança do símbolo se refere ao mesmo símbolo usado por Priest na substituição do quantificador existencial apresentado na página 13-14 da obra Towards Non-Being. 
quantificador particular, comumente (e erroneamente) compreendido como um quantificador existencial.

Nesse sentido, os adeptos do noneísmo afirmam que o que existe (há) é um modo ou nível de existência que se dá pelo quantificador particular (ontologicamente não carregado, como o quantificador existencial). Portanto, os defensores do noneísmo recusam a afirmação de que há coisas que não "existem". Do mesmo modo, nesta teoria não temos nomes vazios e consequentemente o mesmo tomado como um problema. As diversas teorias sobre nomes em particular deixa de ser uma questão. Em suma, o noneísmo compreende que é impossível que objetos possam existir em mundos impossíveis, tanto quanto objetos inexistentes podem existir em mundos possíveis, mas não atuais. 


\section{O espectro do nada}

\section{O Ser e o devir-nada.}

Este capítulo pretende realocar o existir (humano) perante o nada, i.e., um capítulo concebido sob o domínio da moral (ética). Assim sendo, pelas páginas que nos antecedem foi possível atribuir uma semântica ao não ser, um procedimento que visa deslindar um obstáculo epistemológico e indicar o estatuto ontológico de objetos não existentes. Por este desenvolver (acessamos) "o" nada e "o" tornamos "possível". Através de uma abordagem metafísica nos deparamos com um objeto de estudo e através da lógica e da epistemologia procuramos abarcar sua natureza lógica para que um acesso fosse arquitetado e, consequentemente, vinculado ao existir humano. Trata-se de algo não somente vinculado ao âmbito epistêmico, mas também ao agir e a vivência de suas consequências.

Observamos que, soberano, "o" nada não conhece superior nos universos em que habita. Transformado em palavra, sua apreensão imediatamente declara o sepultamento abrupto do conceito, que sequer chega a Ser. Empunhamos a ausência, acreditamos senti-la, mas sua presença se coloca também paradoxal. O que não é, não reside, e como não reside não parece adequado assumir que estamos escancarados "ao" nada, fazendo do existir (humano) sua morada. Igualmente, um mundo (im)possível, que suporte tal objeto, não se faz tão impossível como imaginávamos. O que rondava e ainda ronda sua possibilidade era, ao mesmo tempo, dúbia e insuficiente. A ideia de nada, de alguma forma, se tornara avassaladora.

É nesse sentido que abordar sua existência, em seu aspecto conceitual e pragmático, dá origem a inúmeras questões especificadamente filosóficas que se encontram no coração da metafísica. Saber o que é o existir ou porque qualquer outra coisa existe resulta em saber o que é a natureza do existir, do Ser e se possível, do não ser. A condição de possibilidade de algo que é (ainda que seja o que não é). A gênese dessa circunstância enaltece uma característica própria à consciência e ao homem: a dúvida e o anseio pela fundamentação (rondada pelo espectro do nada).

Sendo a episteme a essência nativa da filosofia, a vontade de conhecer permanentemente a verdade do mundo acaba por destacar a dimensão estável do conhecimento, dentro do qual são levantadas e concebidas as mais diversas apreensões, quais se colocam como substância(s). Este perguntar-se exalta uma necessidade de caráter metafísico e lógico. Se a razão ou uma crença (dita verdadeira e justificada) para o que existe deve vir de outro algo que realmente exista, segue-se que o alicerce para tal desenvolvimento pressupõe uma fundamentação anterior, senão primeira e superior. Por isso, ao perguntarmos o que existe, ou como indagou Leibniz "por que há algo em vez do nada?" - destaca-se o anseio pela estabilidade do pensar e do existir.

A isto a tradição filosófica chamou de Ser, cuja essência indica a fundamentação e possibilidade de um existir. Se diferindo da pluralidade das coisas do mundo por ser a particula- 
ridade última de algo possível. No entanto, este proceder não se mostra tão indubitável quanto parece. De modo igual, ao procurarmos estabelecer a fundamentação de uma apreensão através da crença de que se apreendemos algo é porque esse algo existe, pela justificação da justificação ou pelo devir, somos estorvados por uma irresolução do pensar que assume dispositivos destrutivos. Pelo desassossego de uma causa primeira, associamos à nossa mente a possibilidade de uma cadeia de causalidade. Se toda proposição requer uma justificação e consequentemente imputada por um valor de verdade, assume também um pano de fundo metafísico, todo Ser parece nos indicar outro Ser, fazendo com que a ideia de uma condição de possibilidade primeira imploda pela existência de um fundamento do próprio fundamento e assim infinitamente. ${ }^{1}$ Prevalece uma contingência (que flerta com o imutável) e não a necessidade.

Reflexão explicitada por muitos filósofos, sendo um deles, Bergson:

\begin{abstract}
"Mal comecei a filosofar e já penso nas razões por que existo; e, depois de me aperceber da solidariedade que me liga ao resto do universo, vejo que apenas transferi para mais longe a dificuldade, pois quero saber por que existe o universo; e, se atribuo o universo a um Princípio imanente ou transcendente que o suporta ou que o cria, o meu pensamento só durante alguns instantes se fixa nesse princípio; volta a surgir o mesmo problema, dessa vez com toda amplitude e generalidade: de onde vem, como compreender que alguma coisa exista?"
\end{abstract}

BERGSON, P.300. 2010 - A evolução criadora.

Por este vaguear, somos lançados na angústia de Ser, um pavoroso problema que parece simplesmente anunciar como evidência a transcendência da dúvida sobre qualquer certeza. Pela ausência de uma causa, o esgotamento de uma fundamentação resulta no distanciamento do Ser, impondo o negativo. Ao passo que a apreensão dessa ausência ocorre somente enquanto saber de um não saber, o que nos resta? A negação do conceito de Ser, o não ser (nada).

Por um incômodo mais que teórico, a reflexão filosófica procurou diagnosticar essa situação pela análise de um raciocínio lógico, perscrutando, sem sucesso, um solo seguro em meio à contingência, i.e., a ideia do existir e do imutável no tornar-se. A saída mais fácil e imatura teria sido inviabilizar a possibilidade "do" nada considerando a dificuldade imposta pelo seu conceito. Foi assim que alguns filósofos ${ }^{2}$ alegaram que "o" nada como conceito não é mais que uma simples palavra e um pseudoproblema filosófico, ou seja, o nada não significa coisa alguma e é algo.

Dado que se a segurança de um procedimento lógico indica a inviabilidade "do" nada como sendo algo, ainda permanecemos diante da vivência de suas consequências. Nos referimos

1 ALMOSSAWI, A. An illustrated book of bad arguments, Jasper Collins Publishers, NY, 2013; Ad Infinitum: Qualquer proposição requer uma justificação. No entanto, qualquer justificação em si só requer uma justificação. Isso significa que qualquer proposição pode ser infinitamente questionada.

2 Bergson em "A evolução Criadora" classifica "o" nada como uma falsa questão; Quine também aborda existenciais negativos e "o" nada em seu artigo "On what there is"; Russell (obra: On denoting) lida com a admissibilidade ontológica através da teoria das descrições, etc. 
“ao" nada (acreditamos nos referir), falamos sobre o nada, pensamos no nada, entretanto, não o atingimos.

Nesse sentido, compreendemos que a palavra em si aparece já nas controvérsias que marcaram e ainda marcam a ontologia ocidental. Sua estruturação escancara que nossas linguagens formais se articularam em torno da predicação e com isso passamos a indicar e relacionar atributos que indicam um valor de verdade (o "real"), analisando e denunciando as formas de inferências que aceitamos como válidas.

Pode-se, deste modo, considerar que a afirmação de que algo é funciona como um colocar-se em direção e assumir a possibilidade de um Ser, carregando-o ontologicamente e lançando-o no mundo. Por outro lado, negar a existência de um objeto parece assumir relações entre indivíduos e predicados ser assumir um indivíduo, ou seja, a tentativa de assumir uma propriedade que se aplique a um objeto que simplesmente não existe.

A incompreensão do nada constitui, assim, "uma situação de desnorteamento provocado pela falta de referências, de uma fundamentação que antes representava uma resposta aos porquês" $e^{3}$ como tais, sinalizavam um proceder humano. Este problema e também um paradoxo, como pudemos observar, esclarece melhor a dinâmica que desencadeia o esvaziamento dos pressupostos metafísicos e suscita a irrupção do niilismo.

Reconhecido como uma corrente implosiva, o niilismo não se coloca apenas como uma obscura tentativa de vanguardas intelectuais, "pois, ele agora impregna o próprio ar que se respira. Sua presença multiforme torna-o tão visível que, paradoxalmente, fica difícil apreendê-lo numa definição clara e unívoca; [.. . ] não há um consenso em seu diagnóstico nem na recordação de suas patologias e do mal-estar cultural e metafísico que representa“(Volpi, p.08). Os estudos históricos sobre a gênese do termo acabaram por mostrar como tem sido complexa e variada a manifestação do fenômeno.

Etimologicamente, se o niilismo - do latim nihil (nada) ${ }^{4}$ - pode ser tomado como o pensamento obcecado pelo nada, convém localizá-lo segundo seus vestígios, indicando sua fundamentação. Condição que uma vez apreendida elucida fragmentos em quase toda a história da filosofia ocidental e do existir em que "o" nada surge como um problema central, se manifestando, mas que até aqui foram descritos, mas não fundamentados. Um objeto que se torna culpado por impulsionar um projétil inexistente de uma arma ainda mais inexistente. Portanto, o que significa tomar "o" nada como causa para a aniquilação de pressupostos metafísicos? Nosso ponto de ligação, saindo de um plano explicitamente metafísico e transitando para os aspectos pragmáticos "do" nada no 5 mundo, expõe sintomaticamente o que significa a incompreensão desse objeto. Se uma vez presente nas mais diversas esferas do mundo contemporâneo, a apreensão do seu

\footnotetext{
VOLPI, F. O Niilismo. São Paulo: Edições Loyola, p.08, 1999.

VOLPI, F. O Niilismo. São Paulo: Edições Loyola, 1999.

O uso do "no" enquanto indicativo é proposital. O niilismo não deve ser tomado como parte intrínseca à estrutura do mundo, situação que indicaria o uso do indicativo "do".
} 
conceito é comumente apontada na história do pensamento ocidental ao atingir seu paroxismo, o niilismo. Concebendo filosoficamente a baixeza do pensamento sob todas as suas formas. Resulta que na visibilidade do dúbio, a degradação do Ser se impõe. A ausência e a não fundamentação culminam na falta de interesse perante todo pensar e conduta possível. Ao homem que pensa e vive profundamente "o" nada, tudo se desvanece. No entanto, inferir "o" nada e seus desdobramentos não é necessariamente ratificar o niilismo. Ainda que se pertençam numa recíproca provocação, são dois conceitos que uma vez separados, resultam em diferentes entendimentos. ${ }^{6}$ Se "o" nada é tomado, por vezes, como condição de possibilidade e antecedente para a realização do niilismo, prevalece a incapacidade de indicar sua natureza.

Outrossim, se o niilismo à primeira vista pode ser definido como a implosão da subjetividade, alternativamente, uma descrença em qualquer fundamentação metafísica para a existência humana, ao flertar com o nada, "sua compreensão não recebeu, ao longo do tempo, uma designação consistente, sendo interpretado de modo bastante particular, quase sempre com um pano de fundo ideológico, na tentativa míope de justificar um niilismo ativo e militante“ “. $\mathrm{E}$ assim sendo, tomado como um fenômeno histórico, na maioria das vezes, é examinado como tal.

Por esta compreensão, concebo o niilismo enquanto "dinâmica interna de um processo dissolutivo em que toda uma tradição está envolvida, pressupondo uma verdadeira filosofia da história" (p.07), como destaca Sergio Givone em Historia de la Nada. Isto significa que o intuito que perpassa e retrata uma contemporânea compreensão do niilismo visa também lidar com o esgotamento das estruturas do próprio pensamento filosófico enquanto subsumido ao tempo. Concepção que indica um problema, estamos a pensar o nada inserido no próprio devir. Consequentemente, parecemos aceitar que ele não em solução, mas história. Isso reflete sua devastação nos atos e atitudes frente a vida, antes baseadas na verdade absoluta.

Pela noção de um devir-nada encaramos a vida como uma oscilação entre dois polos não existentes, anterior e pós à existência mesma. Com isso, é precisamente nossa decomposição histórica que se tenta compreender antes de mais nada, ignorando ou afirmando vagamente o que seria pressuposto e anterior a tal condição. O que vale para o niilismo, não vale para o conceito de nada, que é precisamente um conceito e não um acontecimento.

Segundo Franco Volpi, ${ }^{8}$ se o niilismo indica como incerta e precária a situação do homem contemporâneo, "rompendo a estabilidade dos valores morais e conceitos tradicionais; impondo a ausência de finalidade" (p.07), i.e, uma carência de resposta à pergunta "para quê?", não estamos simplesmente elucidado a inóspita e constante presença do não ser (nada) para com os aspetos mais gerais e basilares da existência, mas uma crítica genealógica a partir da frustração da existência diante do devir. De modo que, se é a ideia do mal que dá ao sistema sua dimensão histórica, o devir é então tomado como movimento pelo qual a "humanidade" ${ }^{9}$ se torna

GIVONE, S. Historia de la nada. Argentina: Adriana Hidalgo, p.07-26, 2009.

VOLPI, F. O Niilismo. São Paulo: Edições Loyola, p. 1999.

VOLPI, F. O Niilismo. São Paulo: Edições Loyola, 1999.

9 Entendo por "humanidade" o conjunto de particularidades que indicam a unicidade que é a condição humana. 
culpada e desconfortável a si sem assumir uma razão (fundamental). Ponto que justifica porque concebemos a negação ou a ideia de "nada" e niilismo como algo ruim. Tamanha condição aparenta destruir tudo aquilo que possibilita a ilusão de Ser e apreender o imutável (mesmo que no devir). Compreensão legitimada por Cioran:

\footnotetext{
"A temporalidade da existência introduz um elemento vazio no devir, pois tudo o que se consome no tempo prova implicitamente a sua inconsistência. Felizes são aqueles que podem viver no momento, que podem viver o presente absoluto, que só estão interessados na beatitude do instante e no encantamento pela eterna presença e eterna atualidade das coisas" (CIORAN,E. M. P.104, 2012 - Nos cumes do desespero).
}

Não se trata, portanto, da violência "do" nada, mas da mudança e, por conseguinte, a ideia de uma perda do que um dia acreditamos possuir. ${ }^{10}$ É deste modo que a noção de transição é compreendida como uma relação do nada ao devir (e vice versa) e não do nada ao Ser (o Ser é impossibilitado). Circunstância que uma vez pensada ao seu limite nos indica o solapar de uma fundamentação, insistindo que tudo está inserido num devir-nada e desencadeará ao final de tudo, a derrocada total no não ser (nada). Logo, adotar o nada inserido na historicidade para se impor contra a própria história é apenas utilizar o inexistente como uma ferramenta que espelha o enfraquecimento do que é, não o compreendendo. Por esta perspectiva apenas assumimos sua presença ínfima como parte de um processo de esgotamento, não sendo o nada mesmo. Afirmar que a crise de valores através da historicidade seria pretexto de punição para a condição humana é ignorar a punição bruta, i.e, a condição humana por si mesma, ilusoriamente fundamentada na penumbra de um devir-nada.

O cerne dessa questão encontra-se melhor desenvolvido na obra "The essence of nihilism" de Emanuele Severino. Ao reinterpretar a história da filosofia ocidental como a responsável pela grande loucura, i.e., a crença de que as coisas vêm do nada e retornam ao nada, ${ }^{11}$ Severino compreende como consequência dessa conjuntura a consolidação da realidade concebida sobre um nada radical e fundamental. Justificando o tratamento do mundo como um objeto de exploração, degradação e destruição.

Um primeiro passo é compreender que a abordagem de Severino não se trata de uma apologia ao niilismo, mas uma constatação que se refere à estrutura do ocidente e sua gênese. Uma "civilização assombrada pelo nada", a convicção de que "o" nada é algo, ou de alguma forma, se tornou algo. Com isso, Severino reivindica ${ }^{12}$ dois pressupostos essenciais para

Procedimentos epistêmicos, culturais, sociais, existenciais, etc. O termo não deve ser confundido como um indicativo do conjunto de características específicas à natureza humana, i.e., bom, mau, egoísta, etc. A ideia de que algo nos torna comum uns aos outros a partir de nossas particularidades indica apenas uma ilusão do indivíduo no sentido de amparar sua própria existência enquanto parte de um corpo social.

10 A ideia de que o tempo destrói tudo.

11 SEVERINO, E. Essence of Nihilism. Edição inglesa. Tradução de Giacomo Donis, Londres: Verso, p.313, 2016.

12 O uso dessa palavra indica os esforços de Severino para recuperar algo que pertence a (ou está na posse de) outra pessoa. Explicitamente, contrário às muitas visões que estruturam o pensamento ocidental, Severino busca compreender a gênese do niilismo e "do" nada como condição de possibilidade para o mesmo. Termos que, 
a compreensão e o diagnóstico do niilismo:

1. Nada passa/nada muda.

2. Tudo é eterno (antidevir).

O filósofo busca ilustrar que o que não aparece, permanece, e permanece para sempre, porque não há um lugar para que tenha sido, seja (é), ou deixará de Ser. Oposição explícita ao pensamento imposto pela tradição filosófica, ou seja, que não é possível um lugar em que as coisas que não se manifestam, ou que não aparecem, possam residir. Com isso, Severino não está oferecendo um lugar, pois, ontologicamente falando, o nada só pode residir em um não-lugar, suportando sua totalidade negativa. Mas, considerando sua eternidade negativa, ele jamais deixará de ser porque sequer chegou a ser, ele se justifica na sua impossibilidade.

É por isso que Severino compreende como condição de possibilidade para a primazia negativa do niilismo o devir e não uma (não) fundamentação que do e pelo nada. É pela ideia do tornar-se, presente em toda a história da filosofia que emerge o lamento pelo Ser, pela impossibilidade e incapacidade de racionalizar a lógica do vir-a-ser.

Por esta lógica, Severino se baseia em dois filósofos no intuito de esclarecer sua insurreição contra uma ideia do nada concretizada na cultura e no pensamento ocidental. É através de Nietzsche e a noção do eterno retorno que Severino compreende o conceito de eternidade em oposição ao nada e, por conseguinte, proclama uma disposição antagônica ao pensamento de Heidegger e o desespero do mesmo ao lidar com a inadequação da linguagem em conceituar o evento que caracteriza a mudança [da história] do Ser. Severino se opõe à submissão do Ser à tirania do tempo. Em sua visão primordial, o niilismo caso levado até sua gênese tem sido e é justamente pelo intento da redução do Ser como um produto do tempo. ${ }^{13}$ Uma manifestação que elucida, em última instância, a possibilidade da coisa que se mostra e é, estar contida e completamente amparada sob o alicerce da produção e da destruição. O prazo de validade do Ser consiste na funcionalidade do devir.

Em suma, o pensamento de Severino se coloca como uma construção anti-platônica e anti-Heráclito. Adepto dos preceitos parmenídicos, para Severino, toda aparência é, não importa o quanto enganadora seja, desde que não resida fora do Ser. Sendo que, como o mesmo aponta que tudo exista (Ser) para sempre e seja eterno (não há devir) não significa que o eu empírico seja imortal no tempo - pois, convém explicitar uma importante discrepância conceitual e comumente confundida, imortalidade não significa eternidade. E ao passo que cada momento, cada pedaço de realidade é, tudo é para sempre, desde que não seja tomada como algo que vem a ser ou deixe de "Ser", pois, sempre será. O devir é aniquilado.

Examinemos nas páginas que se seguem como o Ser, tal como abordado por Severino,

segundo ele, foram deturpados ao longo da história do pensar por serem inseridos no devir e na degradação do pensar filosófico subsumido ao tempo.

13 SEVERINO, E. Essence of Nihilism. Edição inglesa. Tradução de Giacomo Donis, Londres: Verso, p.10-12, 2016. 
deve ser pensado dissociado da temporalidade, pensamento que uma vez assumido, evidencia a soberania ilusória do devir sobre um nada em si. Com isso, podemos indicar os processos de consolidação do Ocidente a partir do esgotamento das categorias ontológicas. ${ }^{14}$

\title{
3.1 Niilismo, devir e o retorno à Parmênides
}

\section{O coração de tudo e o sentimento “do" nada.}

“(...) No estado em que me achava, se viessem me avisar que eu poderia voltar tranquilamente para casa, que minha vida estava salva, ficaria indiferente; algumas horas ou alguns anos de espera dá na mesma, quando se perdeu a ilusão de ser eterno."

- Jean Paul-Sartre, in “O Muro” (Erostrato).

"A coisa mais misericordiosa do mundo, creio eu, é a incapacidade da mente humana em correlacionar todo o seu conteúdo. Vivemos numa plácida ilha de ignorância em meio a negros mares de infinito, e não está escrito pela Providência que devemos viajar longe. As ciências, cada uma progredindo em sua própria direção, têm até agora nos causado pouco dano; mas um dia a junção do conhecimento dissociado abrirá visões tão terríveis da realidade e de nossa apavorante situação nela, que provavelmente ficaremos loucos por causa dessa revelação ou fugiremos dessa luz mortal rumo à paz e à segurança de uma nova idade das trevas."

- Howard Phillips Lovecraft, in "O chamado de Cthulhu"

Em sua obra, Essence of nihilism, Emanuele Severino insere-se no debate ontológico iniciado por Heidegger, mas que, ao contrário deste, propõe um retorno ao pensamento antigo de Parmênides. Assim sendo, a questão principal a que nos atentaremos remonta à filosofia clássica e diz respeito à contradição ou ao acordo com o mesmo, entre o Ser e o não ser (nada), rondado pelo tornar-se (culminando no devir-nada e no niilismo).

\begin{abstract}
"A crença de que o Ser é nada é niilismo. Em um sentido profundamente diferente de Nietzsche ou de Heidegger, o niilismo é a essência do Ocidente. (SEVERINO, E. p.313, 2016. Essence of Nihilism).“15
\end{abstract}

Com isso, o filósofo aborda o problema a partir de dois autores atuais, Nietzsche e Heidegger. Nesse sentido, o capítulo que se segue realiza uma exposição das visões de Severino à luz destes dois filósofos no intuito de explorar o que o autor intitula como "a essência do niilismo", i.e., a fundamentação do Ocidente.

Segundo Severino, o erro do Ocidente consiste em distanciar-se dos preceitos de Parmênides segundo os quais apenas o ato de Ser é e pode ser pensado e definido. Ao escolhermos

14 A argumentação que se segue é toda baseada na obra: SEVERINO, E. Essence of Nihilism. Edição inglesa. Tradução de Giacomo Donis, Londres: Verso, 2016.

15 Tradução de minha autoria: The belief that being is nothing is nihilism. In a sense abysmally different from Nietzsche's or Heidegger's, nihilism is the essence of the west (SEVERINO, E. Essence of Nihilism. Edição inglesa. Tradução de Giacomo Donis, Londres: Verso, p.313, 2016). 
não respeitar os ensinamentos do Eleata, seduzidos pelo conceito de "tornar-se" no pensamento e na história, o Ocidente encontrou-se numa situação sem saída que trouxe o atual domínio da razão, da ciência e da tecnologia. De outro modo, essa tríade emerge e passa a ser valorada a partir da concepção de que certos mecanismos ${ }^{16}$ capazes de conceber a estruturação do mundo falharam ou foram insuficientes. Em vista disso Severino argumenta que devemos retornar à Parmênides, pois a grande doença e alienação que se instaurou na estruturação do Ocidente ocorreu depois que o pensamento grego passou a, em vez de considerar apenas o "existente", também evocou o "tornar-se" pretendido como uma dimensão visível, onde as coisas se originam do nada e retornam ao nada, depois de terem sido retidas temporariamente no "existente". A isso, Severino se refere como a alienação da razão que implica a alienação do significado do tornar-se rondado pela ideação do imutável. Cita ele:

\begin{abstract}
"A alienação da razão implica um significado alienado do tornar-se. [... ] Seja notado: se o devir é entendido, por definição, como a anulação do Ser ou como aquele que emerge pelo nada, então a verdade do Ser proíbe que o mesmo "se torne" e seja imutável. Mas o problema, agora, é outro, a saber: O "tornar-se" aparecer como tal anulação ou como tal "emergência? Em outras palavras, o "tornar-se" que se manifesta/aparece como tal não pode ser predicado do Ser? “ SEVERINO, E. Essence of Nihilism. Londres: Verso, p.107, 2016). ${ }^{17}$
\end{abstract}

Deste modo, o "tornar-se" é tomado como uma oscilação entre o "existente" e o nada. Contudo, sabido que Severino se recusa a aceitar que o "tornar-se" é o caso, a estrutura filosófica de Severino pode ser compreendida por três aspectos:

- A primazia do "tornar-se", substituindo o Ser (parmenídico), atinge seu paroxismo na estruturação da ontologia ocidental na ideia de um nada radical à existência que se manifesta enquanto angústia. Com isso, "o" nada que emerge pelo devir se dá numa relação dialética com o Ser, onde o "existente" ou aquilo que é, jamais chega a Ser. Por se colocar como parte de um devir que não se completa, não há a possibilidade de uma unidade real em harmonia pelas partes contrapostas.

- Severino elucida que o esforço do homem, em lidar com o "tornar-se", explicita uma "lógica da reparação", ou seja, o homem, angustiado pela instabilidade do vir-a-ser, ainda preza pela imutabilidade numa espécie de defesa para justificar um proceder existencial. Por esse aspecto, o ocidente levanta a ideia de coisas imutáveis e as vincula a tudo que é possível Ser. Com isso, constrói-se a entidade (Deus) e valores transcendentais e permanentes (éticos, naturais, etc...).

16 Religião, filosofia, arte, etc.

17 Tradução de minha autoria: "The alienation of reason implies an alienated meaning of becoming. [...] Be it noted: if becoming is understood, by definition, as the annulment of Being, or as Being's emerging from nothingness, then the truth of Being prohibits that Being become and proclaims it to be imutable; but the problem, now, is another, namely: does Becoming appear as such annulment or as such emergence? In other words: is the Becoming that appears a becoming that cannot be predicated of being $i$ "

(SEVERINO, E. Essence of Nihilism. Londres: Verso, p.107, 2016). 
- A obsessão pela imutabilidade que se dá através da lógica da reparação acaba por encontrar na força da episteme um anseio filosófico circunscrito pela vontade de atingir um conhecimento certo e seguro que indica a "verdade" do mundo. Por tal proceder, o Ocidente se fundamenta no esforço de indicar uma imutabilidade até mesmo no devir.

Assim, nossa estruturação existencial atual passa a assumir mecanismos (ciência, tecnologias, religiões, filosofia e as artes) que flertam com o imutável, ou seja, os grandes parâmetros inventados pelo homem, para se tornarem cada vez mais poderosos pós a morte de Deus (Ser máximo). Não obstante, seria possível inserir nesta lista a estruturação política do mundo, que de certa forma abrange estes âmbitos, tornando a crescente bifurcação entre o desejo e o capital, o mais novo impulso para uma outra compreensão de niilismo, pautado nos estados de esgotamento e a biopolítica. ${ }^{18}$

Nesta nova paisagem, podemos destacar que "o conhecimento será definido como conhecimento para o mercado", ${ }^{19}$ como aponta o filósofo Achille Mbembe; aspecto que já esta mais do que consolidado e nos direciona à concepção de Severino sobre a produção de um saber considerando um nada radical. Severino argumenta que a tecnologia baseada na ciência moderna tornou-se o instrumento mais poderoso de transformação do mundo. Mas o lugar que contém todos os outros lugares é a totalidade da ideia do "existente". A filosofia pretende indicar seu rosto.

Foi assim que, em primeiro lugar, afirmamos a existência de Deus, que é o Ser imutável que nenhum poder humano pode dominar. Depois, a filosofia de nossos tempos mostrou que nenhum Deus, imutável e eterno, pode existir. Portanto, primeiro seu caminho foi bloqueado por Deus e suas leis; então a filosofia removeu o caminho de cada obstáculo. Ironicamente, a cristianismo está seguindo o mesmo destino da filosofia, com o agravamento de deixar de lado o espírito de crítica com que a filosofia tenta argumentar os motivos da necessidade da imutabilidade que serve de defesa e refúgio em relação ao "tornar-se" e é comparável à criação do desejo de poder que Nietzsche se refere.

Assim sendo, as coisas imutáveis, antecipando e controlando o "tornar-se" sufocam e ameaçam a vontade de existir. $\mathrm{O}$ homem, como uma engrenagem do fracasso, continua a persistir e anunciar, como uma âncora para a sua segurança, a ciência e tecnologia. Buscando se libertar dessa ameaça que é o vir-a-ser.

A filosofia moderna tende então a se afundar no conhecimento científico, porque é a própria negação e destruição da imutabilidade. Com relação a isso, Severino afirma que "a filosofia vai necessariamente para o seu próprio declínio, isto é, para a ciência, que, no entanto, é o método em que a filosofia vive hoje. Para Severino, todo o conhecimento, um dia imputado

18 Para mais informações: PELBART, Peter Pal. O avesso do niilismo: cartografias do esgotamento. São Paulo: N-1 Edições, 2013.

19 Trecho retirado do artigo: "The age of humanism is ending" (2016). 
como aquele capaz de atingir ma verdade, encontra-se reduzido a termos científicos. De outro modo, o mesmo foi declarado por Heidegger: "Agora, só um deus pode nos salvar": "a filosofia está no fim. [...] O que foi a função da filosofia até hoje foi herdada pelas ciências. [... ]"20 A filosofia se dissolve em ciências únicas: psicologia, lógica, ciência política. Mas se ambos se assemelham nesta noção, porque Severino se opõe a Heidegger?

Severino aponta que o abandono do "Ser" de Parmênides e a escolha do "tornar-se" é a loucura do Ocidente, o caminho da noite, ${ }^{21}$ o espaço original onde as formas da cultura ocidental, com suas instituições sociais e políticas, mudaram e se consolidaram. Diante da angústia do "tornar-se", o Ocidente, respondendo à lógica da reparação que nunca chega a ser o que é, evoca o imutável (Deus, leis da natureza, dialética, livre mercado, leis éticas ou políticas, etc).

Temos então um primeiro pressuposto para entender a relação entre "o" nada e o niilismo tomado enquanto aspecto pragmático de um devir-nada, i.e., através de um ser-no-mundo estruturado sob a proteção de uma civilização ordenada pelo aparato da tecnologia.

Severino então compreende que, no início da nossa civilização, Deus, o primeiro técnico, cria o mundo do nada e pode empurrá-lo para o nada. Hoje, a tecnologia, o último Deus, recria o mundo e pode aniquilá-lo. Em suas obras, Severino pretende então questionar a fé, a crença do "tornar-se" no qual o Ocidente se ampara, com a convicção de que o homem deve buscar um recurso positivo contra a angústia que essa fé gera. $\mathrm{O}$ "tornar-se" é uma multidão de Sísifos.

É deste modo que, ao ecoar Nietzsche, ${ }^{22}$ Severino conclui que não só nenhum Deus imutável e eterno pode existir, mas também que esse Deus que emerge como uma contraposição recursiva ao "tornar-se" não deve considerar o vir a ser como um curso retilíneo e irreversível, mas um círculo que se fecha para sempre. A capacidade e necessidade desse círculo é o que conhecemos pelo conceito de "super-homem", que possui uma vontade mais poderosa de qualquer outro. Deste modo, saber que o caminho é circular, é necessariamente mais poderoso, tanto no processo quanto na atuação, do que quem, desconsiderando-o e acreditando que o curso é retilíneo, continua aquém dessa noção de progressão que circunscreve o tornar-se. Portanto, a tecnologia orientada pela ciência moderna, tecnologia que hoje se afirma como o poder supremo do homem, pode ignorar que o curso dos eventos no mundo é circular? Pode ignorar o traço fundamental do mundo? Uma tecnologia que deve ignorá-la pode não ser impotente em relação à tecnologia que a conhece e coloca esse conhecimento como sua própria base ${ }^{23} \mathrm{E}$, dessa maneira,

20 Trecho a partir de entrevista concedida por Martin Heidegger à revista alemã Der Spiegel em 23 de Setembro de 1966 e publicada após sua morte em 26 de Maio 1976. Por intermédio desse diálogo, Heidegger relata a questão das transformações técnico-cientificas em nossa sociedade e o rumo que estas podem acarretar para a humanidade.

21 “The path of the night”; SEVERINO, E. Essence of Nihilism. Edição inglesa. Tradução de Giacomo Donis, Londres: Verso, p.107- 118, 2016.

22 NIETZSCHE, F. Assim Falou Zaratustra. Tradução: Eduardo Nunes Fonseca, São Paulo: Hemus, 1985.

23 Na obra Gaia Ciência (112), Nietzsche recusa a inferência de que a ciência nos leva a verdade. Para Nietzsche, a 
não possamos nos preparar para admitir o que pensamos ser a afirmação mais paradoxal, de que a doutrina do eterno retorno levanta a tecnologia ao ápice de suas possibilidades?

Ora, Severino pode parecer paradoxal, mesmo absurdo ou até inconcebível, porque sustenta que tudo é eterno. Não apenas todo homem e coisa, mas também todos os momentos de vida, cada sentimento, cada aspecto da realidade. Como consequência, nada desaparece, nada morre: a eternidade é a nostalgia do não vivido.

Se grande parte da humanidade acreditou por milênios que as coisas e os homens nascem do nada e retornam ao nada, simplesmente aceitamos que nascer significa: sair do nada, morrer significa retornar ao nada: o vivo é aquele que sai do nada e retorna ao nada. ${ }^{24}$

Em todo caso, tudo é eterno para Severino. Mas isso não é suficiente: apenas na superfície acreditamos que as coisas vêm do nada e que, em nada, finalmente precipitarão, porque no final estamos convencidos de que o breve segmento que é a vida não é nada. A isso Severino chama de niilismo. Temos então uma segunda compreensão para o termo.

Compreensão que elucida, em última instância, o principal homicídio, a aniquilação última, o assassinato do Ser. Contudo, é também uma contradição que é, segundo Severino, "a loucura do Ocidente" e agora se encaminha, impulsionado pela globalização, como a loucura de toda a Terra. Uma enfermidade que precisa de muitos confortos, da razão, da religião, da arte.

Sob este prisma, Severino considera que, uma possível sensatez está nos esperando, a aparência da eternidade de todas as coisas. Segundo ele, ao anunciar as coisas dessa forma, depreende que somos eternos e mortais porque o eterno entra e sai do estado de aparência. A morte é o estado de ausência do eterno. Condição que anuncia uma alternância na compreensão da morte e "do" nada. Não retornamos ao nada, porque sequer chegamos a ser alguma coisa.

Pode-se talvez exorcizar a morte, adotar um conforto através de religiões, filosofias, mecanismos tecnológicos ou a arte e seu aspecto mais catártico e epifânico. Também podemos acreditar que tudo termina em um grande silêncio, semelhante ao que precede o nascimento. Podese conceber que a ciência consegue prolongar a velhice, os prazeres que procuramos atormentar avidamente, as preocupações acumuladas durante os dias. Pode-se tudo a quem aceita a ilusão de Ser algo. Até mesmo morrer. Por isso, o Ocidente, cuja pré-história é o Oriente, interpreta a morte como aniquilação, salvo por algum caso em que a alma ou a consciência continuariam a ter uma vida própria. Do mesmo modo, enquanto a compreensão oriental do existir já parte da existência mesma, ou seja, ao nos perguntarmos quem somos, o oriente responde "O que eu sou não interessa, o que interessa é que sou”; o ocidente e sua obsessão pela fundamentação que emerge pela dúvida inicia seu caminhar pela premissa de que não é; E se não somos, apenas persistimos no transitar que é inquirir “O que eu sou?", "O que é?”. Por essas e outras razões 2016. 
o existencialismo ${ }^{25}$ e o humanismo se consolidaram como correntes capazes de elucidar a primazia do tornar-se, todavia, pautado na ideia de que se chega a Ser alguma coisa, valorando a possibilidade do homem se realizar precisamente como tal.

Concomitantemente, a pergunta "o que se é" parece que só pode ser respondida na medida que não se é mais alguma coisa. Se considerarmos que o homem se faz na medida em que existe e só vem a ser enquanto totalidade do seu Ser na medida em que deixar de Ser, ou seja, após sua morte, simplesmente indicamos a existência enquanto um vir-a-ser incapaz de assumir seu Ser mesmo (devir-nada).

Severino ${ }^{26}$ tenta então demonstrar que a persuasão de que qualquer coisa ou qualquer evento (homem, planta, estrela, situação, instante) pode ser aniquilado e que a aniquilação é nada, é essencialmente uma "grande loucura". É a insensatez mais profunda que pode se manifestar não apenas no mundo humano, mas no Todo.

Esta condição domina a história da terra em diversas formas; sendo que a eternidade de tudo e de cada evento aparece fora dessa loucura. Mediante o exposto, a morte, de acordo com Severino, pertence à demonstração do que é eterno, é um evento interno a esta demonstração. A morte não se coloca como uma espécie de alimpadura do Ser, mas pelo contrário, é parte do nosso Ser. É uma condição necessária para a felicidade. Estamos destinados a uma felicidade inatingível, que é a superação de todas as contradições e não um presente dado. É uma necessidade e é inevitável que, após o declínio da vida e da morte, da vontade e da apatia, o homem seja feliz.

Com essa perspectiva, Deus não é o demiurgo ou tomado como o primeiro técnico, mas a aparência infinita dos eternos, essencialmente diferente da tradição religiosa e filosófica. Deus não está em outro mundo: no final, somos a superação da totalidade de todas as contradições. É por isso que uma vez a presença do nada acaba por solapar pressupostos metafísicos vinculados ao divino, a imposição da razão apenas dá procedimento a um conflito que não se pode vencer. A verdade substitui Deus, que é um remédio para a angústia do "nada", "a dor do medo da morte“. ${ }^{27}$ Deus está dentro da loucura, do niilismo e da crença de que as coisas morrem.

A tecnologia deve ser tomada não como capaz de se adaptar à sistemas que governam o mundo, mas é ela mesma que governa os destinos da humanidade. A tecnologia continua sua jornada sabendo que não vai encontrar nenhum obstáculo e qualquer limite insuperável. Igualmente, a filosofia atual tornou a tecnologia totalmente gratuita, ela a elevou ao topo das suas possibilidades. A voz da filosofia do nosso tempo, a tecnologia agora pode adotar um ritmo muito

25 SARTRE, J.P. O Existencialismo é um humanismo. Editora Vozes, Rio de Janeiro, p.59-62, 2002.

26 SEVERINO, E. Essence of Nihilism. Edição inglesa. Tradução de Giacomo Donis, Londres: Verso, p225-230, 2016.

27 "Então, a seu ver o outro Deus existe mesmo?

- Não existe, mas ele existe. Na pedra não existe dor, mas no medo da pedra existe dor. Deus é a dor do medo da morte. Quem vencer a dor e o medo se tornará Deus. (Dostoiévski, F. Demônios, Os. Tradução de Paulo Bezerra, p.120, Editora 34, São Paulo, 2005). 
diferente e essencialmente mais forte. $\mathrm{O}$ instrumento (tecnologia em geral, as novas tecnologias em particular, as redes de telecomunicações e de informação) está se tornando objeto, o objetivo da comunicação.

Os primeiros pensadores começaram a compreender que o Ser era o Todo, além do qual havia "o" nada: sendo que este não é algo que pode ser conhecido ou do qual se pode falar, como vimos no início deste trabalho. É nesse sentido que Parmênides é importante, pois, ele aprofunda e interpreta o conceito de "Ser". Na verdade, se o "não ser" não é, não pode se dividir no Ser e dividi-lo em partes; nem pode ser algo a partir do qual o Ser sai ou se afunda. Nesta argumentação de Parmênides, o princípio fundamental lógico da "não contradição" é utilizado, de acordo com o qual um objeto e seu complemento não são simultaneamente aceitos como pertencentes à mesma realidade.

Parmênides observa que é logicamente contraditório afirmar que o "não existir" existe, que o Ser existe, porque o não ser é o contrário do Ser e afirmar a mesma realidade para um objeto e seu contrário é um erro lógico: um absurdo. Portanto, o surgimento do Ser é, e assim sendo, coloca-se uma opinião falsa, uma aparência ilusória de que os mortais que seguem o curso da "não verdade", que é de aparência, se tornam convictos. Com a mesma linha de raciocínio, Parmênides admite que o Ser nunca nasceu, nem morrerá nunca, é eterno. Portanto, assim como o citado no primeiro capítulo, para se afirmar que algo nasce, deve-se admitir que esse algo foi gerado por outra coisa e assim por diante, mas como o "ser" é único, isso é logicamente contraditório. Pelo mesmo motivo, não podemos aceitar que o "Ser" se move, porque mover-se desempenha a noção de passar de um lugar para outro e prosseguir em um elemento, espaço vazio, o "não estar", o que deve permitir o movimento e isso é também contraditório.

Severino, refletindo sobre Parmênides e sobre a história da civilização ocidental, que tem um lugar no centro do "tornar-se", a loucura que domina o mundo, chega à afirmação de que tudo é eterno. Tudo é eterno significa que todo momento de realidade "é", que não é sair e não retorna ao nada. Isso também significa que o triunfo que geralmente reservamos para Deus também deve ser dado às coisas e eventos mais humildes e impalpáveis. Todo sentimento e pensamento nosso, toda forma e "nuance" do mundo, cada gesto do homem é eterno. E também tudo o que aparece todos os dias e em todos os instantes: a nossa primeira lágrima, o último suspiro, Brasília antes e após sua construção, nossa angústia e seu cadáver. Todos os instantes do mundo e todo o conteúdo do mundo é eterno. Mas então como se deve proceder? Falar sobre algo não atinge esse algo, o que se intenta não pode ser visto. Até quando viveremos sob a secreção do não ser? Indicamos um proceder e parecemos abrandar a evocação importuna do negativo, mas somos incapazes de permanecer encerrados em nós mesmos e assim, continuamos a nos relacionar com espectros, dentre eles, o do niilismo reforçado pela ideação de um devir-nada. 


\section{CONCLUSÃO}

O presente estudo apresentou um pequeno sistema filosófico, explorando e refletindo sobre "o" nada e o não ser, inquirindo o que significa admitir algo ontologicamente. Sendo o texto dividido em três capítulos, iniciei a minha abordagem situando o domínio do discurso na metafísica, passando pela lógica, epistemologia e concluindo no campo da ética. Por esta construção, procurei elucidar como uma estruturação ontológica compreendida como capaz de auxiliar um proceder epistêmico e existencial se mostra incerta, i.e., também contingente. Dada tal condição, analisei os critérios ontológicos a partir de um procedimento lógico-ontológico, considerando uma semântica e como esta se relaciona com proposições indicando o que é o "real".

Na primeira parte do trabalho explicitei como se deu a impossibilidade do nada (tomado enquanto não ser) no pensar e na linguagem para que, em seguida, pudéssemos questionar os critérios subjacentes. Ao lidar com os primórdios da ontologia ocidental, observamos que a mesma se estrutura a partir do PI (princípio da identidade) parmenídico, este que se consolida, em última instância, por conceber o ente em oposição ao não ser. Ao tomarmos os termos "pensar" e "Ser" enquanto sinonímias, elucidamos um problema ontológico por inferir segundo tal princípio que pensar um objeto é pensar necessariamente um objeto existente, i.e., pensar um objeto e pensar o mesmo enquanto existente são a mesma coisa. Aspecto que indica uma primeira concepção sobre o "real" (parmenídico): "tudo existe". Por esta via "o" nada é inviabilizado.

Em seguida, procurei dissecar o que Parmênides compreende pelos termos "existe" e "Ser". Esta questão acaba por destacar uma inquirição acerca dos nossos paradigmas de admissibilidade ontológica. Ao passo que não podemos afirmar a não existência de algo sem nos comprometermos com a existência desse algo que afirmamos não existir, lidamos com um problema. A isso a tradição filosófica chamou de "o paradoxo do não ser" (contemporaneamente conhecido como "o problema dos existenciais negativos"), ou seja, se X não existe, concebemos que existe uma coisa que não existe. Nesse sentido, "o" nada se coloca como um objeto "possível" que só se manifesta pela sua impossibilidade, o que isso quer dizer? Ao tomarmos o problema ontológico (do não ser), este pode ser formulado de uma forma muito simples (O que é que há?) mas permite um desacordo acerca dos casos e dos objetos em questão. Muitas coisas não existem e esta não existência (apreendida) se dá como possível pela ideação da existência de objetos não existentes, sendo "o" nada, um deles. Portanto, desdenhamos os paradigmas impostos pelo pensamento parmenídico e realocamos os termos "Ser", "há" e "existe", remodelando uma compreensão para o quantificador existencial (até então, carregado ontologicamente) à luz da obra Towards Non Being de Graham Priest. Com isso, pudemos indagar através da argumentação de Russell em Principles of Mathematics que "existir" é ter uma relação específica com a existência, relação que a própria existência não possui. Portanto, tomada como propriedade, a 
existência é algo que se aplica ou não a objetos e não pode ser tomada como aquela que indica a totalidade do Ser de uma coisa, destacando uma realidade (única).

Explicitada tal condição, procurei um meio de acesso ao nada. Apontei que se a existência da palavra ("nada") designa a existência do conceito que clarifica a apreensão do objeto, averiguar o discurso ontológico que circunscreve "o" nada requer a afirmação do mesmo enquanto um objeto do discurso. Isso significa indicá-lo como sendo algo e portar propriedades (ou não). Deste modo, considerando o desenvolvimento que se encontra em Towards NonBeing de Graham Priest, argumentei que um objeto que pertence a um discurso encontra-se compreendido na intenção daquele que o realiza sob uma lógica subjacente. Ao se falar algo sobre algo, essa coisa encontra-se subsumida a universos discursivos que valoram a realidade do objeto segundo a intensidade de suas propriedades e do sujeito intencional.

Sob este prisma, questionar os critérios ontológicos nos remete a uma compreensão lógico-ontológica segundo operadores intencionais. Por considerar a linguagem como meio de acesso ao mundo e, por conseguinte, como direcionamento à aspectos metafísicos capazes de deslindar nossa relação com o que se situa nas fronteiras do pensar, a estruturação de uma lógica pautada em relações de necessidade e possibilidade se faz crucial no entendimento de campos discursivos que não abordam nosso mundo atual, mas abarrotam o campo conceitual e existencial segundo outras estruturações (ontológicas), i.e., mundos possíveis e impossíveis.

Por mundos impossíveis, compreendemos "antirealidades" que se colocam opostas aos princípios lógicos. Assim, a não existência evidencia a incapacidade de uma caracterização pertinente pela dificuldade em realizar uma análise dos mundos subsequentes que se estruturam ontologicamente inferiores e logicamente distintos. Se o "nada" e sua potencialidade só se dá na medida em que não pode vir a ser uma potencialidade, sua apreensão significa se relacionar com uma particularidade paradoxal capaz de explicitar a totalidade última de um objeto, i.e., pelo "nada" nos deparamos com um conceito vazio. Consequentemente, a incapacidade de caracterização pertinente causa um desgaste em diversos âmbitos. A possibilidade de uma redução ontológica do não ser, ou melhor, a realocação do nada numa ontologia pautada em critérios lógicos de primeira ordem é insuficiente. Se a obstrução para uma entidade é o seu critério de identidade, por exemplo, não podemos sequer afirmar o nada, já que este não é igual a si mesmo. "O” nada não é coisa alguma e uma vez (não) residindo num mundo impossível, o mesmo não segue princípios lógicos.

Não obstante, se a palavra e, consequentemente, a linguagem como meio de acesso ao nosso mundo parece não atingir o que não é, por outro lado, falar sobre algo é fazer com que esse algo deixe de ser o que é. Nesse sentido, se não compreendemos como uma teoria ontológica nos compromete e como nos comprometemos com ela, se não temos critérios certos e seguros para indicar uma verdade ou amparar uma epistemologia - assumir verdades, pelo mecanismo que for, explicita um esforço nulo e ilusório. A dubiedade de um critério ontológico culmina na fragilidade dos nossos critérios de verdade. 
Mediante o exposto, no terceiro e último capítulo realizei uma abordagem ética e ontológica, procurando apresentar uma concepção e realocação da "existência" perante o devir, "o" nada e a eternidade. Ao passo que inferir o que é "real" evidencia um Ser e a apreensão do mesmo enquanto particularidade última daquilo que se mostra como sendo, os procedimentos epistêmicos, ao esbarrarem em compreensões que elucidam o devir como possibilidade de um Ser (e não-ser), aclaram o conhecimento e a obsessão pela estabilidade como algo instável. Buscamos o imutável até mesmo no mutável. Com isso, refletimos sobre a existência fundamentada na contingência e suas consequências, condição que enaltece a primazia do devir e instaura o niilismo como paroxismo da incompreensão do nada tomado enquanto algo. Observamos que tal questão, uma vez abordadas e situadas nas fronteiras da consciência, pode ser profundamente destrutiva. Se a crença de que tudo aquilo que se coloca objeto de formulação e compreensão aparentemente torna-se mais suportável, ao mesmo tempo, nos defrontamos com a concepção nefasta de que a expressão seria o simulacro de um acesso ao que acreditamos Ser e possuir. Um mecanismo de reparação do pensar sobre o próprio pensamento que incapaz de atingir o sentido último, encontra seu amparo na mediação da linguagem. O que é formulado realmente tem sua intensidade diminuída? O que a linguagem pode atingir? E caso atinja, lidamos com o real?

Todas essas questões elucidam o esforço e a obsessão do homem pelo que Severino chamou de lógica da reparação, onde até mesmo o devir procura ser compreendido através de uma fundamentação. Essa obsessão culmina na aniquilação do Ser (ou de seres), indicando a existência como um lapso enganoso, um retalho do Ser em meio ao nada. Foi assim que, segundo Severino, a fixação pelo imutável se estabeleceu, em primeiro lugar, na afirmação da existência de um Deus, que é o ser imutável que nenhum poder humano pode dominar. Depois, a filosofia de nossos tempos mostraram que nenhum Deus, imutável e eterno pode existir, sendo que a atribuição em anunciar uma verdade e um conhecimento possível foi tomado pela ciência e a tecnologia (conhecimento técnico e científico).

É por isso que a manifestação "do" nada, comumente relacionada à noção de angústia, se realiza no conflito ontológico e na dificuldade de uma caracterização pertinente instaurada pelo devir. Essa angústia, pautada na noção de que a existência se estabelece enquanto transição, enaltece o direcionamento a um polo concebido como fundamental, que a episteme busca como certo, mas se manifesta inalcançável. Observação depreendida também por Cioran:

\footnotetext{
"Ninguém executaria o ato mais ínfimo sem o sentimento de que esse ato é a única e exclusiva realidade. Esta cegueira é o fundamento absoluto, o princípio indiscutível de tudo o que existe. Aquele que o discute prova somente que existe menos, que a dúvida minou seu vigor... Mas, mesmo no meio de suas dúvidas, é obrigado a sentir a importância de sua tendência para a negação." (CIORAN, “Interpretação dos atos" in Breviário de decomposição. 2011).
}

Se toda ação se manifesta como um ato de crença absoluta justamente pela nossa relação subserviente ao Ser, uma vez que tais critérios solapam, a existência pode ser questionada 
como aquela que existe não apenas como existência e o Ser não sendo apenas o Ser. Critérios metafísicos, lógicos e epistemológicos podem se encaminhar para outras estruturas, se relacionarem com o não ser e isso não os fazem de alguma forma Ser. Com isso temos outra concepção acerca "do" nada, e por mais que o que é se relacione com o que não é, aparentemente indicando um pavimento à existência, este não indica sequer uma verdade, mas apenas uma possibilidade de assujeitamento que é existir sem assumir uma relação última com a existência ou a crença de que algo possa ser conhecido. Condição que uma vez experienciada, pode nos levar a um ceticismo extremo. Questões que uma vez adentradas, nos mostram que não temos mais nada a ganhar ou perder. Viver (na História) pode então perder todo o significado, pois, o momento vivido pode ser tomado com uma tensão tão exagerada, que o tempo se apresenta apagado e irrelevante diante da eternidade. Ponto que busquei esclarecer através de Severino: quão pior seria a eternidade em relação ao absoluto do devir, à morte e ao nada?

Concomitantemente, convém destacar que todo procedimento que julgamos como viável ou contingente, como cita Alexandre Costa-Leite no artigo "Fronteiras contingentes e conhecimento limitado" encontra-se subsumido a uma estruturação, ou seja: "Não basta elucidar o que é a contingência, é preciso também esclarecer em qual sentido o conceito de conhecimento está sendo usado (p.180). Deste modo, a noção de contingência a que me refiro foi averiguada segundo a ideação da existência de objetos não existentes e "o" nada no intuito de analisar nosso meio de acesso ao mundo (linguagem) e inferir que esta não asseguram nada. Mais uma vez, esclarece Costa-Leite sobre a noção de contingência e conhecimento:

\footnotetext{
"A noção de contingência é metafísica, pois está conectada ao conteúdo da estrutura do mundo, isto é, ao próprio mundo visto enquanto um complexo de proposições atuais e possíveis. Proposições acerca da realidade se são verdadeiras podem ser falsas e vice-versa. Qualquer proposição acerca do mundo é, portanto, contingente. As variadas possibilidades de configuração do mundo são manifestações da contingência. Isso significa que o mundo poderia ser de certa forma, mas também poderia ser uma forma completamente diferente. [... Tal mutação dos fatos é fundamento mesmo da contingência. Sem esse fluxo, proposições acerca do mundo seriam necessárias. Todavia, como todos acreditam, não existe garantia alguma de uniformidade da natureza, pois, o período de observação sempre vai ser pequeno diante da infinitude que nos cerca". (COSTA-LEITE, p.180, 2012. Fronteiras contingentes e conhecimento limitado).
}

Uma vez que o bastão da verdade enquanto descrição e explicação do "real" foi passado para a ciência e a tecnologia, sendo esta primeira a responsável por enunciar critérios direcionados a um conhecimento final, a tecnologia personifica o devir ilustrando a possibilidade de uma criação e destruição, beirando ao nada. Preceitos que vinculados a uma estabilidade e uniformidade do conhecimento, insistem na substancialidade do devir e acabam por estabelecer juízos tão devastadores quanto uma realidade única e possível, i.e., imóvel. Se a dúvida e a certeza edificada sob uma racionalidade cartesiana serviram de armas para a civilização ocidental arrogar-se superior e esclarecida, condenando tudo aquilo que não é ou pode ser, 
como proceder? Um conhecimento se mostra impossível e ainda que fosse possível, nada resolveria. Essa é a posição última daquele que duvida. Ao passo que existir-no-mundo se torna ser consciente dessa existência, i.e., o mesmo é pensar e ser, atingimos os cumes de uma relação paradoxal, em que seu ápice esclarece também sua profundidade negativa. Anseio e fracasso consolidado pela lógica explicitada por Morin na obra Rumo ao abismo: "No fundo, toda vontade de ter uma teoria totalmente coerente realiza-se na perda de seu contato com o real, na sua esclerose e no seu endurecimento (2012, p.55).

Conceber o nada ou o Ser, o nada ou eternidade, não nos esclarece nada além da possibilidade de esboçar um sorriso em meio à contingência ou a ilusão de uma realidade do e no mundo. Um desfile de falsos absolutos: A filosofia, a religião, a arte, a ciência e a tecnologia. Por mais que a ciência funcione no mundo atual, nada garante que amanhã se seguirá o mesmo. Considerando que a verdade das premissas não garante a verdade da conclusão, ou seja, um procedimento pelo qual a humanidade tem tanta simpatia, temos que as inferências que fazemos acerca do "real" são basicamente inferências indutivas e não indicam coisa alguma. As leis universais que criamos, formulamos e muitas vezes acreditamos como sendo capazes de prever o futuro, não são exatamente leis no sentido de conter uma necessidade. O mundo pode assumir certas estruturações e não temos nenhuma garantia (última) lógica sobre esses fatos. A indução não garante nada. Portanto, em um lugar em que nada se resolve, permanece a transcendência da dúvida sobre qualquer certeza. 


\section{Referências Bibliográficas}

MBEMBE, A. A era do humanismo está terminando. Revista IHU (Instituto Humanitas Unisinos). Rio Grande do Sul, 24 de Janeiro, 2017.

ABBAGNANO, Nicola. Dicionário de filosofia. 6. Ed. São Paulo: WMF Martin Fontes, 2012.

ALMOSSAWI, A. An illustrated book of bad arguments, Jasper Collins Publishers, NY, 2013.

BERGSON, H. Evolução criadora, A. São Paulo, Ed.UNESP, 2010.

BERTO, F. Existence as a real property: The Ontology of Meinongianism. EUA: Springer, 2012.

CASSIN, Bárbara. Se Parmênides. O tratado anônimo De Melisso Xenophane Gorgias. São Paulo: Autêntica, 2015.

CIORAN, E. Nos cumes do Desespero. São Paulo: Hedra. 2012.

CIORAN, E. Breviário de decomposição. São Paulo: Rocco. 2011.

COSTA-LEITE, A. Fronteiras contingentes e conhecimento limitado. Revista Brasileira de Filosofia, 2012.

DOSTOIÉVSKI, F. Demônios, Os. Tradução de Paulo Bezerra, p.120, Editora 34, São Paulo, 2005).

FREGE, G. Foundations of arithmetic, The. 2.ed. New York: Harper, 1960.

GARRETT, B. . Metafísica: conceitos-chave em filosofia. São Paulo: Artmed, 2008.

GIVONE, S. Historia de la nada. Argentina: Adriana Hidalgo, 2009.

HEIDEGGER, Martin. O que é metafísica. In: Os pensadores. São Paulo: Nova Cultural, 1999

SILVA, Jairo José da. Filosofias da matemática. São Paulo: Editora UNESP, 2007. p.123-134.

LEIBNIZ, G.W. Monadologia e outros textos, A. Organização e tradução de Fernando Luiz Barreto Gallas e Souza). São Paulo: Hedra, 2009.

LEVINAS, E. Otherwise Than Being or Beyond Essence. EUA: Duquesne, 1998.

MEINONG, Alexius. Sobre a teoria do objeto. In: BRAIDA, Celso R. Três Abertruas em Ontologia: Frege, Twardowski e Meinong. Florianópolis: Rocca Brayde, 2005. p. 91-145.

MEINONG, A. Theory of objects, The. In: Realism and the Background of Phenomenology. [S.1.]: The Free Press, 1960. cap. 4, p. 76-117. 
MORIN, E. Rumo ao Abismo? Ensaio sobre o destino da Humanidade. São Paulo, Bertrand Brasil, 2011.

NIETZSCHE, F. Assim Falou Zaratustra. Tradução: Eduardo Nunes Fonseca, São Paulo: Hemus, 1985.

NIETZSCHE, F. Gaia Ciência, A. São Paulo, Martin Claret, 2016.

PARMÊNIDES. Da natureza. Edição bilíngue. Tradução e comentário de José Trindade Santos. São Paulo: Loyola, 2009.

PELBART, Peter Pal. O avesso do niilismo: cartografias do esgotamento. São Paulo: N-1 Edições, 2013.

PLATÃO. O Sofista. Trad. Jorge Paleikat e João da Cruz Costa. In Os pensadores. São Paulo: Abril Cultural, 1979.

PRIEST, G. Towards Non-Being. The Logic and Metaphysics of Intentionality. Oxford U.P Un; Oxford, 2016.

QUINE, W. V. O. On what there is. The Review of Metaphysics, v. 2, n. 5, p. 21-38, September 1948.

RUSSELL, B. On denoting. Mind, v. 114, n. 456, p. 480-493, 1905.

RUSSELL, B. Principles of Mathematics. Cambridge: Merchant Books.

SARTRE, J.P. O Existencialismo é um humanismo. Editora Vozes, Rio de Janeiro, p.59-62, 2002.

SARTRE, Jean Paul. O Ser e o Nada: Ensaio de Ontologia Fenomenológica. $11^{\circ}$ Trad. Paulo Perdição, Petrópolis: Vozes, 2002.

SEVERINO, E. Essence of Nihilism. Edição inglesa. Tradução de Giacomo Donis, Londres: Verso, 2016.

TARSKI, Alfred. A concepção semântica da verdade. São Paulo. Unesp, 2002.

VOLPI, F. O Niilismo. São Paulo: Edições Loyola, 1999.

REICHER, M. Nonexistent Objects, The Stanford Encyclopedia of Philosophy (Winter 2016 Edition), Edward N. Zalta (ed.), 2016. 